\title{
23. LITHOLOGIC FACIES CHARACTERISTICS OF MESO-CENOZOIC DEPOSITS OF DEEP SEA DRILLING PROJECT SITES 464, 465, AND 466, HESS RISE ${ }^{1}$
}

\author{
P. P. Timofeev and V. I. Koporulin, Geological Institute of the U.S.S.R. Academy of Sciences, Moscow, U.S.S.R.
}

\begin{abstract}
The study of composition and textural and structural features of Meso-Cenozoic deposits of Deep Sea Drilling Project Sites 464,465 , and 466 by lithologic-facies analysis enabled us to single out the following macrofacies and facies of sediments:

1) Macrofacies of clay sediments of a deep-water oceanic zone with influence of volcanism (includes the facies of the same name);

2) Macrofacies of clay organic siliceous sediments of a deep-water oceanic zone (facies: organic siliceous clay sediments of oceanic deep-water zone; clay organic siliceous sediments of oceanic deep-water zone);

3) Macrofacies of organic carbonate sediments of the deep-water oceanic zone (facies: radiolarian organic carbonate sediments of deep-water oceanic zone; organic carbonate sediments of deep-water oceanic zone with redeposited fine materinal; organic carbonate sediments of deep-water oceanic zone with redeposited fine and coarse material;

4) Macrofacies of carbonate deposits with sapropelic and humic-sapropelic matter of near-shore sedimentation (facies: carbonate sediments with autochthonous sapropelic microcomponents of a relatively deep-water, near-shore sedimentation zone; carbonate sediments with autochthonous sapropelic and allochthonous humic microcomponents of the shallow-water near-shore sedimentation zone.

Analysis of distribution of macrofacies and facies in a section of the sites testifies to a clear transgressive development of sedimentation in the region, beginning with shallower-water conditions at the end of the Early Cretaceous, and ending in deeper-water conditions in the Cenozoic.

The section abounds in hiatuses, related mostly to redistribution of material by gravity currents promoted by the uneven relief of the basement.
\end{abstract}

\section{INTRODUCTION}

The objective of the study was to determine the facies nature of Meso-Cenozoic sediments penetrated on Hess Rise during DSDP Leg 62, and to reconstruct on this basis the evolution of the sedimentation processes in the region. The method of lithologic-facies analysis was used for this purpose. This method had been worked out at the Geological Institute of the U.S.S.R. Academy of Sciences (Timofeev, 1968, 1969) based on study of primary genetic features of sediments and rocks that reflect the primary environment of sedimentation. These features are color, composition, texture, structure, fossils, interrelationships with other sediments, thickness, etc. With rocks subjected to deep postsedimentary transformations, such studies are intended to eliminate these changes and to reproduce primary features of sediments.

Such an approach to study of sedimentary deposits is advantageous, since it is aimed at a more thorough and detailed analysis of specific features of sediments and rocks, and makes researchers think of their genesis and environments in which the process of sedimentation was proceeding.

The method of lithologic-facies analysis of marine and oceanic sediments was successfully used by the authors in studying Meso-Cenozoic deposits of some regions of the Atlantic and Pacific Oceans (Timofeev et

\footnotetext{
${ }^{1}$ Initial Reports of the Deep Sea Drilling Project, Volume 62.
}

al., 1979). Following this method, some genetic types of deposits, facies, and macrofacies were distinguished. The geological essence of these terms was considered in describing peculiarities of Meso-Cenozoic sediment accumulation of the Bay of Biscay and the Rockall Plateau (Timofeev et al., 1979).

In the course of lithologic-facies study of deposits penetrated during DSDP Leg 62, the authors used personal observations of Dr. V. I. Koporulin, participating on the leg, examination of the photographs of peculiar core samples, various lithologic and paleontologic data obtained by other participants of the leg and summarized in the shipboard files, and the results of a thorough study of core material carried out at the Geological Institute of the U.S.S.R. Academy of Sciences. The study incorporated a microscopic analysis of thin sections of rocks and sediments and the heavy and light mineral fractions singled out from them. Over 400 thin sections and 15 samples of the heavy and light mineral fractions were investigated; unfortunately, only a small part of samples characterizing mostly the basal horizons of the sections in the sites provided the necessary amounts of heavy and light minerals.

The data on composition of minerals of the clay fraction, geochemistry of deposits, and composition of rocks enriched in organic matter (Timofeev, et al.; Varentsov et al.; Timofeev and Bogolyubova, all this volume) were considerably helpful for interpretation of the genetic nature and sedimentation environment in the two regions concerned. Given below are characteristics of the facies composition of sediments at each of the sites. 
A summary of macrofacies and facies is given in Table 1 .

\section{SITE 464}

Hole 464 penetrated a complex of Meso-Cenozoic sediments beginning with the upper Aptian (Fig. 1). Drilling was stopped because of technical troubles after penetrating $16 \mathrm{~cm}$ into heavily altered igneous rocks (pillow-lavas or basaltic sill in the sedimentary pile).

\section{Aptian-Cenomanian Deposits (Lithologic Unit III)}

Lithology of sediments overlying basalts has been poorly studied because of poor core recovery. On the whole, these are nannofossil limestones and chalks containing cherts, gray in the upper part and pink and reddish in the lower part. The limestones are frequently enriched in clay minerals and pass into marls or carbonate clays. According to the shipboard files, the sediments contain deep-water benthic foraminifers as well as planktonic foraminifers and Core 27 contains redeposited benthic forms of a neritic area. The total thickness of this unit is 218.5 meters; the sediments are separated from the overlying deposits by a hiatus. These deposits are attributed to a macrofacies of organic carbonate sediments of the deep-water oceanic zone. We failed to identify various facies among them due to poor core recovery.

\section{The Upper Cretaceous-Lower Miocene (Lithologic Unit II)}

The deposits are represented by brown clays belonging to a macrofacies of clay sediments of a deep-water oceanic zone with influence of volcanism (and the facies of the same name). The rocks are of various brown tints: from pale yellowish- or reddish-brown to dark, almost black. The upper and lower parts of this interval abound in darker colors, and the middle part in lighter colors. Varieties of different color form irregular interbeds, mot-

Table 1. Macrofacies and facies of Meso-Cenozoic deposits penetrated by DSDP Holes 464, 465, 465A, and 466 (Hess Rise).

\begin{tabular}{ll}
\hline \multicolumn{1}{c}{ Macrofacies } & \multicolumn{1}{c}{ Facies } \\
\hline $\begin{array}{l}\text { Clay sediments of a deep-water } \\
\text { oceanic zone with influence of } \\
\text { volcanism }\end{array}$ & $\begin{array}{l}\text { Clay sediments of a deep-water } \\
\text { oceanic zone with influence of } \\
\text { volcanism }\end{array}$ \\
$\begin{array}{l}\text { Clay organic siliceous sediments } \\
\text { of deep-water oceanic zone }\end{array}$ & $\begin{array}{l}\text { Organic-siliceous clay sediments } \\
\text { of an oceanic deep-water zone }\end{array}$
\end{tabular}

of deep-water oceanic zone

of an oceanic deep-water zone

Clay organic siliceous sediments of an oceanic deep-water zone

Radiolarian organic-carbonate sediments of a deep-water oceanic zone

Organic carbonate sediments of deep-water oceanic zone

Organic carbonate sediments of deep-water oceanic zone with redeposited fine material

Organic carbonate sediments of a deep-water oceanic zone with redeposited fine and coarse material

Sapropelic and humic-sapropelic carbonate deposits of a near-shore sedimentation zone
Carbonate sediments with autochthonous sapropelic microcomponents of a relatively deep-water, near-shore sedimentation zone

Carbonate sediments with autochthonous sapropelic and allochthonous humic microcomponents of a shallow-water near-shore sedimentation zone
Clays, with rare, intensely dissolved remains of radiolarians; brown, reddish-brown, dark-gray; homogeneous or with mottles and streaks, sometimes with thin horizontal lamination; contains numerous $\mathrm{Fe}$ - and Mn-micronodules, fragments of acid and basic glass, pyroxene, zeolites

Organic-siliceous clays, sometimes with an admixture of nannofossil remains; gray, brownish-gray, yellowish-brown with mottles and streaks, sometimes of irregular horizontal lamination due to alternation of layers of different color and different content of clay material, remains of siliceous and carbonate organisms

Clay organic siliceous oozes, with an admixture of nannofossil and foraminifer remains; white, gray, olive-gray or pale-brown, homogeneous or with obscure horizontal lamination, mottles and streaks. The lamination is due to alternation of layers of variations colors and different content of clay material, remains of radiolarians, diatoms, foraminifers, coccoliths

Radiolarian foraminifer-nannofossil oozes, white, gray, with greenish tints, homogeneous; non-laminated, with mottles or streaks, or thin irregular horizontal lamination. The radiolarian content varies from 1 to $10 \%$. Acid or basic glass

Nannofossil and foraminifer-nannofossil oozes, white, pale-gray, palebrown, homogeneous; non-laminated with mottles or streaks, or thin irregular horizontal lamination; contains redeposited remains of nannofossils and foraminifers, clay aggregates, fragments of basalts, feldspars

Siliceous nannofossil and foraminifer-nannofossil oozes, white, palegray, homogeneous, non-laminated, with mottles and streaks, sometimes with obscure irregular horizontal lamination; contains fine and relative coarse (some millimeters to $4 \mathrm{~cm}$ ) fragments of basalts, shallow-water mollusks, redeposited remains of coccoliths and foraminifers (shallow-water, benthic), sometimes plant remains

Recrystallized nannofossil and foraminifer-nannofossil limestones and chalk, dark-gray, olive-gray, non-laminated, or with distinct horizontal and multidirectional small cross-bedding lamination. Frequent graded bedding; enriched with sapropelic material; rare fish bones, fragments of mollusks

Recrystallized foraminifer-nannofossil and nannofossil-foraminifer limestones, pale or dark olive-green to black, with a slight greenish tint; distinct horizontal and multidirectional small cross-bedding, rare thin non-laminated interbeds with graded bedding; enriched in sapropelic material, rare humic fragments, plant remains; numerous fragments of fish bones, mollusk remains 


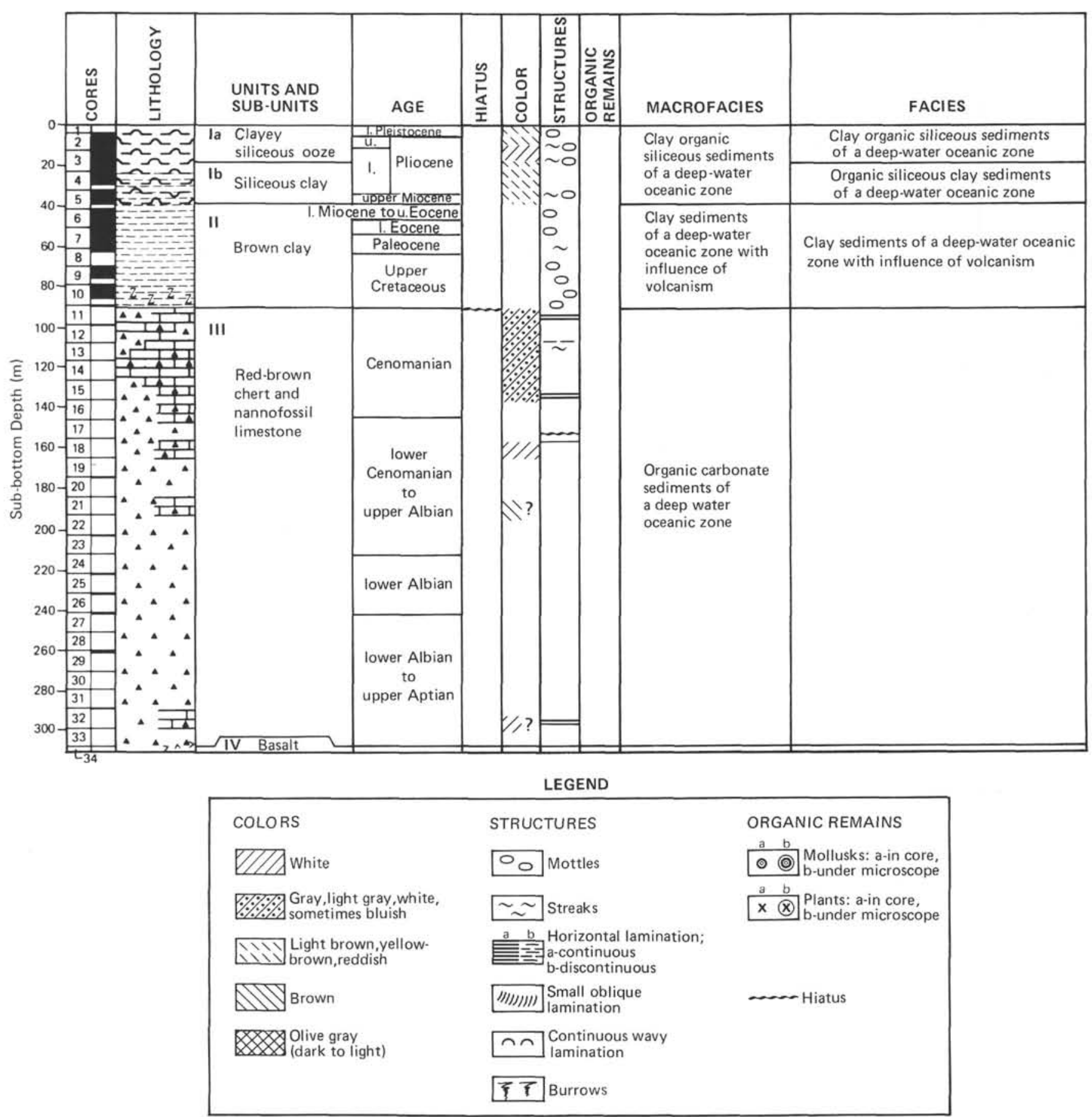

Figure 1. Macrofacies and facies at Site 464.

tles, or zones. They frequently owe their irregular outlines to drilling disturbance (Plate 1, Fig. 1).

Microscopic study showed that the clay mass is of a finely-dispersed structure and consists mainly of particles smaller than $1 \mu \mathrm{m}$, some particles being 2 to $4 \mu \mathrm{m}$. According to the X-ray-diffraction analysis, the clay fraction is presented by mixed-layer montmorillonite-illite, zeolites being present in small amounts.

The clay material of the rocks contains insignificant amounts of Fe- and Mn-hydroxides. They either saturate the entire mass of a rock, or form brown, reddish-brown, or opaque clots and flakes sized from some tenths to some hundredths of a millimeter. Some rounded nodules of such material reach 0.7 to $0.8 \mathrm{~mm}$. Variations in the Fe-hydroxide content make the rock clearly laminated. Constant components of the sediment are fragments of fish bones, plagioclase, and volcanic glass. Fragments of fish bones are sized up to $0.06 \mathrm{~mm}$, their shape being irregularly equant or elongated. Fragments of plagioclase are silt-sized grains, angular or strongly 
elongated, with tabular outlines; most of them are fresh, without any signs of secondary minerals.

Volcanic glass is represented by brown or colorless varieties. The size of fragments does not exceed 0.07 to $0.1 \mathrm{~mm}$. Brown glass occurs most frequently and is usually altered and replaced by clay minerals (smectites); its particles are equant, somewhat rounded. They have no distinct boundaries and pass into the clay background enclosing them. The largest of them contain small crystals of plagioclase. This type of glass likely is of intermediate composition and was brought to the sediments as a product of redeposition of older volcanogenic and volcanogenic-sedimentary rocks, or simultaneously as a result of volcanic eruptions.

Colorless glass is transparent in plane-polarized light; with crossed nicols it is isotropic or shows weak aggregate polarization. Such particles have irregular outlines and are frequently angular; their boundaries with the enclosing clay mass are distinct. This glass variety most likely corresponds to acid igneous rocks and was supplied to the sediments during volcanic activity.

The following components were also recognized in the sediments: semi-rounded fragments of clay material having the same composition as the clay mass enclosing them, poorly preserved radiolarian remains, crystals of phillipsite sometimes forming concretions 2 to $4 \mathrm{~cm}$ in diameter (Plate 1, Fig. 2), irregular segregations of carbonate. Inclusions of cherts up to 1.5 to $2 \mathrm{~mm}$ were recognized in the basal parts of the interval. They are equant or strongly elongated, and sharply angular. They are most likely from local redeposition of older sediments.

The deep-water character of deposits of the facies is evidenced by the practically complete absence of remains of carbonate organisms. These sediments probably were accumulated below the carbonate compensation depth. Besides fragments of basalts and volcanic glass, certain geochemical properties (Varentsov, et al., this volume) testify to the influence of volcanic activity on their accumulation. Thickness of the sediments is $\mathbf{5 3}$ meters.

\section{Upper Miocene-Pleistocene (Lithologic Unit I)}

These deposits are composed of siliceous clay oozes attributed to the macrofacies of clay organic siliceous sediments of a deep-water oceanic zone, including two facies.

The facies of organic siliceous clay sediments of a deep-water oceanic zone is composed of organic siliceous clays. They are of early Pliocene to late Miocene age. The rocks are gray, greenish-gray, brownish-gray, pale-brown, yellowish-brown, brown, or dark-brown. Gray, greenish-gray and pale-brown tints are characteristic of the upper part of the section, and brown tints of the lower part. On the whole, the intensity of brown color clearly increases downward through the section.

The varieties differing in color form mottles, thin lenses, and interbeds, the thickness of the latter varying from less than a centimeter to some tens of centimeters (Plate 1, Fig. 3). Disturbances of structures by drilling make it difficult to estimate the thickness and interrelations between separate layers. Color differences are related to variations in the content of clay and siliceous material, variations in $\mathrm{Fe}$ - and $\mathrm{Mn}$-concentrations, and the oxidation state of the sediment. Fe- and Mn-hydroxides frequently form irregular segregations some centimeters in diameter, or in thin films.

According to microscopic study, the rocks consist mostly of finely dispersed clay material and remains of siliceous organisms.

The clay material is brownish-gray and composed of an aggregate of disordered particles not over 2 to $3 \mu \mathrm{m}$ across. X-ray-diffraction analysis of the clay fraction showed the polymineralic character of its composition and the presence of such minerals as illite, chlorite, and mixed-layer illite-montmorillonite.

Siliceous organisms in the sediment amount to 10 to $45 \%$ (visual evaluation), their content being higher in the upper part of the interval. Predominant among them are remains of radiolarians, represented by wellpreserved large forms or fragments of various sizes. Remains of diatoms are in much lesser amounts; still less abundant are sponge spicules and silicoflagellates. In Core 4 , there is also finely dispersed carbonate material (possible altered remains of nannofossils), its concentrations being higher in the upper parts. The rocks usually contain nodules of brown, highly argillaceous glass and ferromanganese micronodules. Thickness is 17.3 meters.

The facies of clay organic siliceous sediments of an oceanic deep-water zone is represented by clayey organogenic-siliceous, mostly radiolarian oozes or siliceous clays. They were recognized in Cores 2 to 4; in Core 1 and the upper part of Core 2 there are only manganese nodules.

The sediments are gray, greenish-gray, olive-green, and olive; there are varieties of pale-brown and yellowish-brown color. The latter occur mostly in the lower part of the interval. The coloring is rather irregular; there are in a sediment irregular mottles, lenses, streaks, and layers, differing both in color and in the ratio of clay to siliceous material (Plate 2, Figs. 1, 2). Varying concentrations of ferrous and ferric iron are responsible for the variegated coloring.

Examination of thin sections of the sediments under a microscope showed that siliceous organisms, making up 40 to $50 \%$ of the entire material, are of primary importance in their composition. Clay particles amount to 35 to $45 \%$, remains of carbonate organisms (nannofossils and foraminifers) 10 to $15 \%$. In the character of organic remains, structure, and mineralogy of the clay fraction, these sediments are similar to the abovedescribed facies.

Sediments frequently contain irregular fragments of brown glass replaced by clay minerals, feldspars, and segregations of Fe-sulfides. The latter are concentrated mostly inside radiolarian tests.

Shipboard identification of siliceous organisms in the sediments showed that mixing of water masses of tropical (or subtropical) and high-latitude areas was proceeding at that time in the vicinity of Site 460 , resulting in 
high biological productivity. Nannofossils and rare planktonic foraminifers in the sediments are intensively corroded. Benthic deep-water foraminifers are slightly corroded. The clay fraction of the sediments is polymineralic, consisting of illite, chlorite, and mixed-layer montmorillonite-illite.

The thickness of deposits of the facies is 15.3 meters; the facies is connected by a gradual transition with the underlying one.

The scarcity or absence of planktonic carbonate organisms and the corrosion of those present in the sediments enable us to attribute the deposits to an oceanic deep-water environment. The observed benthic foraminifers are deep water kinds as well. It should be emphasized that the content of organic carbonate decreases downward through the section; at the base (Core 5) it is nil.

All these data show that the accumulation of sediments of the macrofacies was proceeding near the carbonate compensation depth. We may assume that somewhat lesser depths corresponded to sediments with carbonate skeletons, and greater depths to sediments without them. It is possible, however, that a change of the carbonate compensation depth took place during this time.

It was mentioned above that the complex of siliceous organisms in sediments of the macrofacies appeared under conditions of mixing of water masses of high and low latitudes; similar relationships are characteristic of the ocean near Site 464 today.

\section{SITE 465}

At the base of the Meso-Cenozoic sedimentary rocks penetrated at Site 465 are igneous rocks (trachytes). The overlying carbonate sediments cover the interval from Albian to Pleistocene (Fig. 2).

\section{Albian-Cenomanian (Lithologic Unit II)}

These deposits correspond to a unit of olive-green, laminated limestones, rich in organic matter, at the base of the section, representing the macrofacies of sapropelic and humic-sapropelic carbonate sediments of the near-shore sedimentation zone. The macrofacies include two facies.

The facies of carbonate sediments with autochthonous sapropelic and allochthonous humic microcomponents of a shallow, near-shore sedimentation zone includes the basal limestones (Cores 37-40). The rocks are characterized by distinct horizontal lamination or gentle cross-lamination (Plate 3, Fig. 1). Both types of lamination are due to alternation of laminae not over $1-\mathrm{mm}$ thick differing in color and size of the material composing them. Cross-bedding decreases upward in the section, whereas horizontal lamination increases.

There are also non-laminated sediments of paler color. They are most characteristic of Cores 37 and 38, their thickness being 10 to $15 \mathrm{~cm}$. The lower boundary of such interbeds is distinct; upward in the section they pass gradually but rapidly into cross-bedded or horizontally bedded rocks. The alternation of the interbeds- their lower parts being composed of paler, non-laminated limestones, and the upper parts of darker, horizontally laminated limestones-imparts rhythmicity to this part of the section, resembling the rhythmicity of turbidites.

Just above the lower boundary (Core 40 ) the limestones contain numerous irregular fragments of alkaline plagioclase, of sand and fine-gravel size. Interbeds of limestone considerably enriched with humic-sapropelic material are common here (Plate 3, Fig. 3; Plate 4, Fig. 1). Horizons of volcanic ash replaced by finely dispersed smectite were observed at the boundary with trachytes of the basement. Like the limestone, such horizons have horizontal or small cross-lamination. They contain numerous segregations of finely dispersed organic matter on the bedding planes (Plate 4, Figs. 2,3), and thin interbeds $(2-3 \mathrm{~cm})$ of limestone as well.

Microscopic study of the limestones in thin section shows that the rocks are composed mostly of finely aggregated carbonate material (size of particles 0.01-05 $\mathrm{mm}$ ) representing recrystallized nannofossils; few and poorly preserved remains of the latter being clearly seen in some samples. Remains of large foraminifers with chambers filled with calcite or barite are common; their content varies from 10 to over $30 \%$. There are also radiolarians, partly or wholly replaced by calcite, and fragments of bivalve and gastropod shells, fish scales and bones, and fragments of crustacean tests. The size of such fragments varies from parts of a millimeter to 3 $\mathrm{mm}$ along the axis. Angular or tabular crystals of albite and strongly weathered basalt, or trachyte are observed. They are especially numerous in Core 40 , where their size frequently reaches 1.0 to $1.5 \mathrm{~mm}$.

Fine sapropelic material in the rock (its content reaching $8-9 \%$ ) is of brown or golden-brown color, forming irregular elongated clots and flakes 0.01 to 0.05 $\mathrm{mm}$ in diameter. Inclusions of humic material of the same size are of brown or reddish-brown color, frequently opaque. Uneven distribution of organic matter imparts a distinct micro-lamination to a rock. This is emphasized by accumulation of foraminifers, orientation of elongated fragments of fish bones and scales, and remains of bivalve and gastropod shells.

Constant components of the sediment are segregations of pyrite of irregular or rounded shape; frequently these are rectangular, or even square in cross section of crystals. They are either dispersed among finely crystalline carbonate material saturated with organic matter, or localized in chambers of foraminifers.

Study of the heavy minerals showed that besides predominant authigenic pyrite $(\sim 85-90 \%)$ the following minerals are present: zircon, magnetite, apatite, rutile, sphene, monazite, sphalerite (cleiophane), and clinopyroxenes.

Thickness of the facies is $\mathbf{3 5}$ meters.

The facies of carbonate sediments with autochthonous sapropelic microcomponents of a relatively deep-water near-shore sedimentation zone (Cores 2636) is usually represented by a rhythmic alternation of members, in each of them the lower part being com- 


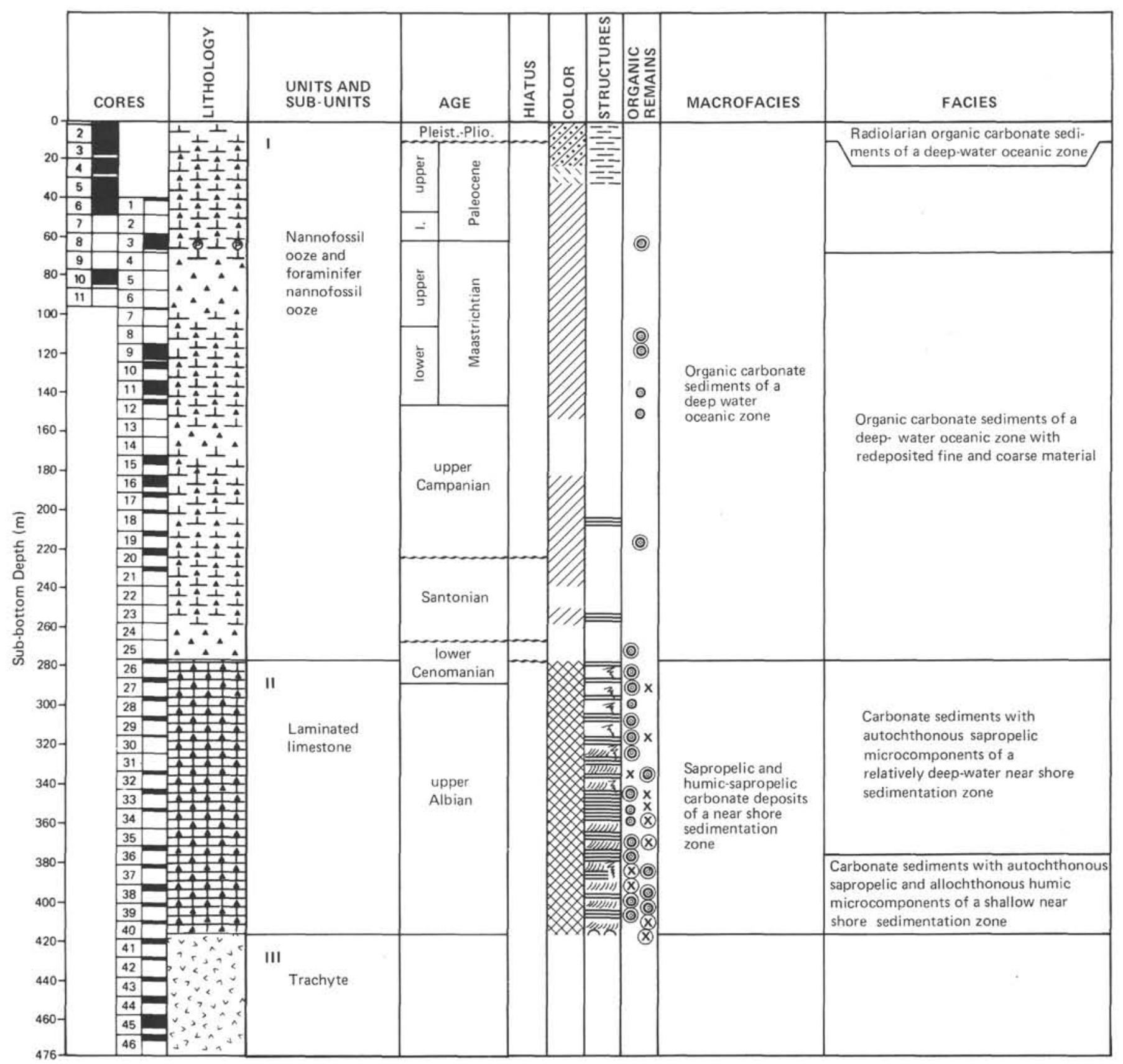

Figure 2. Macrofacies and facies at Site 465. Symbols as in Figure 1.

posed of a non-laminated, homogeneous variety (sometimes with stirring and slumping structures), and the upper one with distinct or indistinct horizontal lamination.

Thickness of the horizons of non-laminated rocks varies from some centimeters to $20 \mathrm{~cm}$. They consist of silt- to clay-sized carbonate material, with gray or palegray color. The lower boundary of such interbeds is distinct, frequenlty uneven. Upward in the section, they pass rather gradually into rocks with distinct horizontal lamination (Plate 2, Fig. 3; Plate 4, Fig. 4; Plate 5, Figs. $1,2)$. This transition is expressed in the appearance of rare-and then more and more numerous-horizontal laminae (up to 1.5 -mm thick) of a darker color, contain- ing foraminifers of coarse-silt size. Flattened, horizontally resting fragments of greenish-gray limestone with distinct horizontal lamination were recognized in one such horizon. There a mollusk shell fragment in another horizon (Plate 6, Fig. 2). Thickness of interbeds with distinct horizontal lamination varies from 3 to $30 \mathrm{~cm}$.

In some places a distinct or indistinct horizontal lamination is peculiar to both the paler, coarse-grained and the darker, fine-grained varieties of limestones (Plate 2, Fig. 3; Plate 5, Fig. 3; Plate 6, Fig. 1).

Thickness of some members reaches $60 \mathrm{~cm}$. Each of them resembles turbidity current deposits. Peculiarities of structure and mechanism of formation of the latter 
are described in the works by Kuenen (1953) and Bouma (1962). Non-laminated varieties of the above-described members correspond to horizon "a," and horizontally laminated ones to horizons "b" or "d" of the turbidity series described by Bouma.

The specific features of the material composition established by means of microscopic study are similar to those of the underlying facies. There are, however, certain differences as well. These are: a lower content of foraminfers (up to $20 \%$ ), fragments of fish bones and scales, and gastropod and bivalve shells. Somewhat different is the structure of sapropelic material. It is distributed more or less evenly in non-laminated varieties of these deposits, whereas in horizontally laminated ones it concentrates in thin laminae although the degree of concentration is much lower than in the above-described facies.

The set of heavy minerals is identical to that from the underlying deposits: pyrite, (up to $90 \%$ of all heavy minerals), zircon, magnetite, rutile, sphene, monazite, sphalerite (cleiophane), clinopyroxenes.

The apparent thickness of deposits of the facies is 101.5 meters; it may be incomplete, because of postsedimentary erosion. The high degree of lithification of the laminated limestones sharply distinguishes them from the overlying complex.

This macrofacies is a rather specific type of sediment accumulated under shallow-water conditions, at a depth not exceeding several hundreds of meters. This is evidenced not only by peculiarities of composition and structure, but also by the fact that the underlying trachytes (as the petrologists of the leg concluded) were formed under subaerial or shallow-water conditions.

Study of sedimentation in recent oceans and seas shows that areas of accumulation of sediments with a high content of organic matter are characterized by low oxygen concentrations in bottom waters, and frequently by free hydrogen sulfide. Often these are zones with weakened circulation of bottom waters and a stagnant regime. This fact does not imply complete quiet or the absence of horizontal water movement at the bottom. In the Black Sea, with its high degree of stagnation and contamination of thick water masses with $\mathrm{H}_{2} \mathrm{~S}$, there are currents of up to $30 \mathrm{~cm} / \mathrm{s}$ at a depth of some hundreds of meters, and up to $10 \mathrm{~cm} / \mathrm{s}$ below 1000 meters (Philippov, 1968).

Such hydrochemical and hydrodynamic conditions were likely characteristic of the sedimentation basin existing during Albian-Cenomanian time within the southern part of the Hess Rise: the low oxygen content in the bottom water (or even the presence of free hydrogen sulfide) was associated with horizontal movements of bottom waters.

Sediments of both facies contain abundant fragments of shallow-water benthic organisms (ostracodes, bivalves, gastropods), fish bones and scales, and remains of terrestrial plants. It is likely that benthic organisms originally inhabited the shallow-water areas, with oxygen content sufficient for life. Their transportation into deeper parts of the basin with lower concentrations was accomplished by gravity currents.
The abundance of fish remains in the sediments is related to times of an abrupt upward displacement of the euxinic layer. This resulted in mass death of the fish fauna. Similar phenomena are rather characteristic of present-day upwelling zones with a high content of organic matter (southwest coasts of Africa and South America) (Baturin, 1978). Remains of altered terrestrial plants bespeak the presence of land (islands, probably) covered with luxuriant vegetation.

The lower horizons of the macrofacies (Cores 37-40) represent shallower water than the overlying horizons (Cores 26-36). This is evidenced by a wider distribution of cross bedding in the former, higher concentrations of organic matter, the presence of numerous terrestrial plants, and remains of a shallow-water benthic fauna, abounding in redeposited fragments of feldspars and basalts.

Geological observations show that stagnant, oxygenfree conditions appeared in marginal or intercontinental seas with a limited connection with the open ocean (Byers, 1977). Such a regime was also peculiar to the shelf zone or the continental slope if the bottom was within the layer of oceanic water with minimum oxygen content (Fischer and Arthur, 1977). As evidenced by geophysical data, the surface of igneous rocks forming the base of the sedimentary complex on Hess Rise is very uneven: uplifts and depressions of various amplitudes are present here. This considerably favored the formation of isolated and semi-isolated basins with bottom waters poor in oxygen.

\section{Santonian-Pleistocene (Lithologic Unit I)}

This time is characterized by accumulation of nannofossil and foraminifer-nannofossil oozes and chalks with inclusions of chert fragments. The deposits are attributed to a macrofacies of organic carbonate sediments of the oceanic deep-water zone. Three facies alternating upward in the section were distinguished.

The facies of organic-carbonate sediments of a deepwater oceanic zone with redeposited fine and coarse material (Cores 465A-4 to 465A-25; Cores 465-9 to 465-11) is of early Cenomanian to late Maestrichtian age. The facies is represented by consolidated nannofossil and foraminifer-nannofossil oozes and chalks. The sediments are white, pale-gray or gray, and homogeneous and non-laminated (Plate 6, Figs. 3, 4), less frequently with obscure irregular lamination disturbed by drilling. Lamination is obviously due to alternation of rocks somewhat differing in color and content of foraminifers. Irregular mottles and streaks are present too.

Indistinct rhythmicity is seen in the sediment. Thickness of rhythms varies from 0.5 to 1.5 meter. The base of each is composed of homogeneous structureless ooze with high amounts of foraminifer tests. Upward in the section, the amount of foraminifers considerably decreases, and the sediment becomes more fine-grained. Irregular horizontal lamination, mottles, and streaks are sometimes observed here. Each rhythm is separated from the underlying one by a distinct, sometimes uneven boundary. Such rhythms appear to be deposits of turbidity currents. The given facies contains rede- 
posited Inoceramus fragments, varying from tiny pieces visible under a microscope to large fragments reaching 3 $\mathrm{cm}$. They are well rounded.

Fragments of cherts are gray, dark-gray, and black, their size varying from a few millimeters to a few centimeters (Plate 6, Fig. 4). Some are rimmed by porcellanite, or contain voids filled with porcellanite. Chert fragments vary from rare to numerous. The largest numbers occur in the lower parts of the facies. It may be that many of them, like the Inoceramus remains, are redeposited.

Microscopic study of thin sections shows that the content of nannofossils reaches 75 to $80 \%$. Shapeless crystals of carbonates (up to 2-3 mm), recrystallized skeletons of these organisms, are observed, too. Foraminifers amount to 15 to $20 \%$. Their chambers are frequently filled with pyrite; small segregations of pyrite or irregular aggregates can be identified within finely dispersed carbonate material composed of coccolithophorid remains. There are few particles of golden or brown basic volcanic ash replaced by clay minerals, grains of glauconite, phosphate, chitinous grains, or zeolites.

As the shipboard files show, foraminifers observed in the sediment are represented mostly by planktonic forms peculiar to low latitudes. Benthic forms characteristic of great depths are found as well. Both the foraminifers and nannofossils contain species redeposited from older sediments.

Thickness of deposits of the facies is 209 meters; these sediments are separated from the underlying sediments by a considerable hiatus.

The facies of organic-carbonate sediments of a deepwater oceanic zone with redeposited fine material (Cores 465-2 to 465A-3) is of Paleocene age. The facies is composed of nannofossil oozes, white or pale-gray, with a slight greenish or bluish tint, homogeneous, non-laminated, or with poorly pronounced, irregular, horizontal (continuous and discontinuous) lamination due to interbeds and thin streaks of material differing in color and size. Irregular mottles of multicolored material are present as well.

Rhythmicity similar to that in sediments of the underlying facies is frequently seen in the sediments. Small amounts of angular chert fragments up to $1 \mathrm{~cm}$ in diameter were recognized. Remains of shallow-water-mollusk tests are common and can be seen in thin sections only.

When judged by microscopic structure, the sediments of the facies are analogous to those described above. The content of coccoliths and foraminifers reaches 75 to $80 \%$ and 15 to $20 \%$, respectively. Grains of aluminosilicate minerals, mostly alkaline plagioclase (up to 0.07 $\mathrm{mm}$ ) are common. Fragments of basic glass can be observed as well.

Paleontological data in the shipboard files show that coccoliths and planktonic foraminifers are represented by forms of low latitudes; deep-water benthic foraminifers and forms redeposited from Cretaceous deposits can be recognized. In Core $465-4, C C$, redeposited shallow-water foraminifers and fragments of ostracodes were recognized. However, the content of redeposited material in the sediments is insignificant. Thickness of deposits of the facies is 60 meters; the facies grades into underlying deposits.

The facies of radiolarian-bearing organic carbonate sediments of a deep-water oceanic zone (Cores 465-1 and 465-2) are of Pliocene and Pleistocene age. The facies consists of foraminifer-nannofossil oozes of gray or pale-gray color with a slight greenish tint. Differently colored varieties form separate interbeds, mottles, and streaks, imparting to the sediment a distinct or obscure horizontal lamination (continuous or discontinuous). Thickness of interbeds varies from a few millimeters to a few centimeters. Besides various colors, they are frequently characterized by different contents of foraminifers. Variations of color are due to different pyrite contents. The sediments are complete devoid of chert fragments and shallow-water-mollusk tests.

Microscopic study of thin sections revealed, along with predominant nannofossils and foraminifers, siliceous organisms: radiolarians, diatoms, sponge spicules, silicoflagellates. According to the shipboard files, radiolarians are related mostly to middle latitudes; there are also forms peculiar to subtropical and subarctic latitudes. This testifies to the mixing of waters of warmer and colder climatic zones. Foraminifers amount to 10 to $40 \%$; species peculiar to temperate latitudes prevail among them.

Constant components of the sediments are particles of acid and basic glass. The former is colorless, and fresh, and does not contain authigenic minerals; the latter is of golden-brown color and usually contains finely dispersed clay particles. Segregates of iron sulfide are numerous. They are mostly frequently observed in inner chambers of radiolarians and foraminifers. Thickness of deposits of the facies is about 3 meters. The facies is separated from the underlying deposits by a considerable hiatus.

The deep-water environment of accumulation of the macrofacies is reliably diagnosed because of the abundance of planktonic organisms (coccoliths, foraminifers) and the presence of deep-water benthic foraminifers. It was likely a bathyal zone of the ocean, not exceeding however the carbonate compensation depth.

Reworked material in many parts of the section and rhythmicity of structure of sediments testify to redistribution of the material on the bottom, possibly as a result of turbidity flow.

\section{SITE 466}

The section of Meso-Cenozoic sediments penetrated by Hole 466 (Fig. 3) is similar in cornposition to that of Hole 465 .

\section{Upper Albian}

These sediments are olive-green and dark-gray limestones and chalks rich in organic (sapropelic) material. They are not laminated, but show indistinct stirring structure or horizontal lamination near the base, visible because of uneven distribution of foraminifers. Fragments of black chert and dark clays are frequent. According to microscopic study, the sapropelic material 


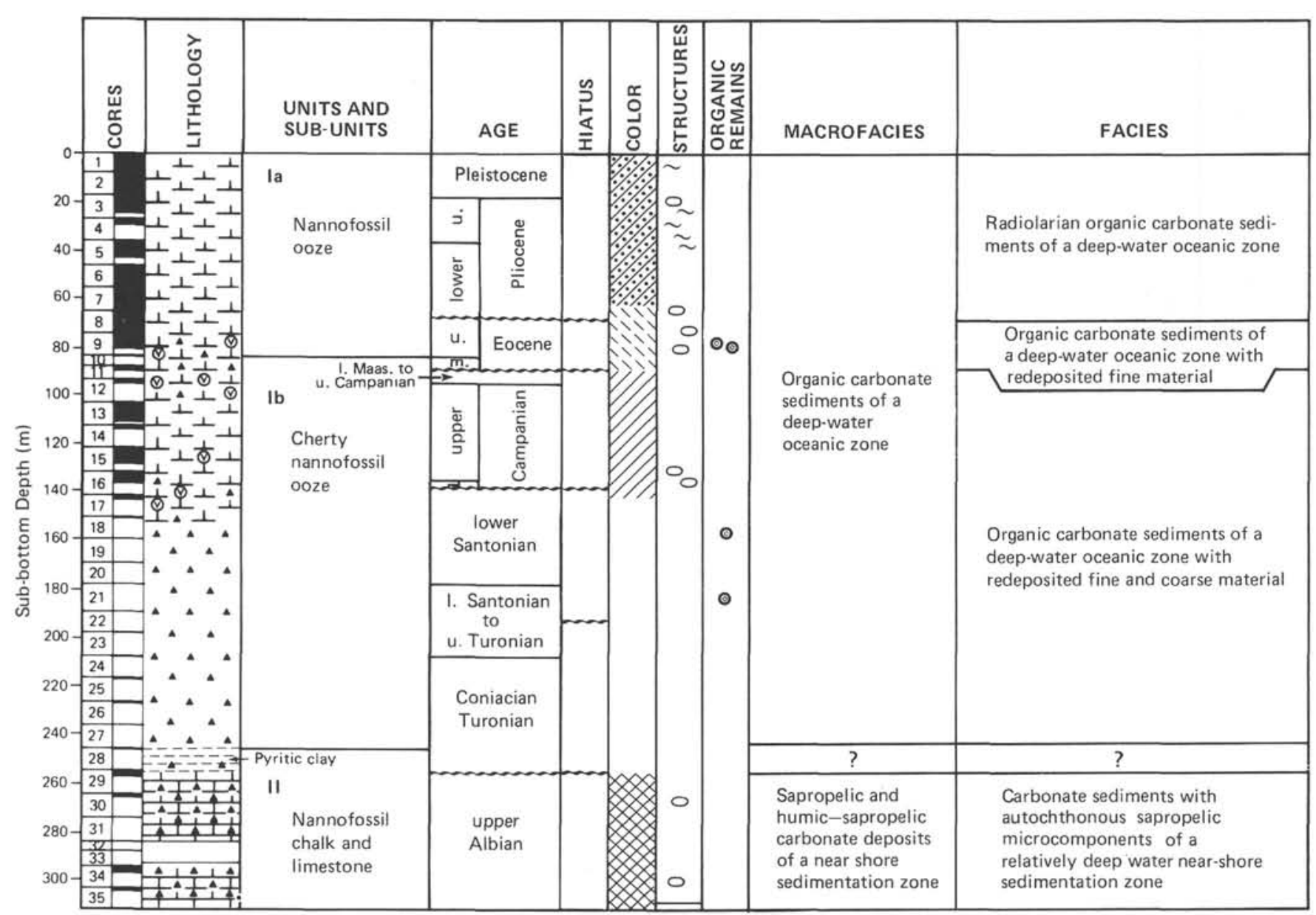

Figure 3. Macrofacies and facies at Site 466. Symbois as in Figure 1.

is more or less evenly distributed in the rocks. Fragments of bivalve and ostracode tests, fish bones, remains of radiolarians, and diatoms occur as well.

These sediments entirely correspond to the facies of carbonate sediments with autochthonous sapropelic components of a relatively deep-water, near-shore sedimentation zone. However, sediments of this facies at Site 465 are distinguished by lesser lithification and much more limited distribution of laminated structures. This appears to indicate that at Site $\mathbf{4 6 6}$ carbonate sediments enriched in organic matter accumulated at greater depths than such sediments at Site 465 . Thickness of these deposits penetrated by Hole 466 is 57 meters.

\section{Turonian to Pleistocene}

A very thin interbed of black, pyrite-bearing clay occurs at the base of these deposits. Their facies nature is not clear. The rocks contain fragments of black cherts and vesicular basalts. However, it may be that these fragments were introduced from the overlying parts of the section in the process of drilling. The mineral composition of the clay fraction (Fe-smectite) is similar to that of the clay fraction of underlying limestones. The sediments are separated from the underlying deposits by a considerable hiatus.
A sequence of nannofossil and foraminifer-nannofossil oozes and chalks composing the overlying sediments of Hole 466 (Lithologic Unit I) belongs to the macrofacies of organic carbonate sediments of an oceanic deep-water zone.

The lower deposits of the macrofacies (Cores 18-27) is poorly sampled: only angular fragments of cherts colored pale-gray, gray, and dark-gray or black, with rims of, and cavities filled by, porcellanite, were recovered. Nannofossil ooze enclosing the cherts was washed out; a high content of coccoliths in the water extracted from tubes bespeaks its presence in this part of section.

The macrofacies contains three facies types of sediments. They are very similar to deposits from Site 465 in composition and location in the section.

The facies of organic-carbonate sediments of a deepwater oceanic zone with redeposited fine and coarse material (Cores 11-17) represents the early Santonian to early Maastrichtian. It is composed of nannofossil and foraminifer-nannofossil oozes, white, cream, or creamwhite, homogeneous, mottled, or with horizontal lamination strongly disturbed during drilling. The sediments usually contain irregular fragments of chert of various tints of gray, dark-gray, and brownish-gray, semirounded fragments of vesicular basalts and trachytes 
(relatively fresh or heavily altered), as well as tuffs, tuffsandstones, and fragments of the prismatic layer of Inoceramus shells.

Microscopic study of thin sections shows that coccoliths make up 80 to $95 \%$ of the sediment, and foraminifers from a few percent to $20 \%$. Irregular fragments of plagioclase, semi-rounded fragments of heavily weathered basalts, and pyrite segregations are common.

Apparent thickness of deposits of the facies is 66.5 meters. These sediments are likely to compose the underlying part of the Upper Cretaceous complex, 95meters thick (Cores 18-27) in which chert was mainly recovered.

The facies of organic carbonate sediments of a deepwater oceanic zone with redeposited fine material (Cores 6-10) accumulated during the middle Eocene to early Pliocene. It is represented by nannofossil oozes, white, gray, brownish- and pale-gray, homogeneous, with mottles and horizontal laminations highly disturbed by drilling.

The redeposited material in these sediments is visible under a microscope only: irregular fragments of relatively fresh plagioclase, semi-rounded fragments of strongly weathered igneous rocks, segregations of brown clay particles, fragments of bivalve and gastropod shells. Phillipsite is common; sporadic particles of humic organic matter and chert fragments are present as well. The highest content of all these components is in the lower part of the facies (Core 9); they gradually decrease upward in the section.

The clay fraction in sediments of the facies has a polymictic composition represented by montmorillonite, chlorite, and illite. A small admixture of kaolinite is recognized in the upper part. Thickness of the facies is 38 meters. The deposits are separated from the underlying sediments by a hiatus.

The facies of radiolarian organic carbonate sediments of a deep-water oceanic zone (Cores 1-5) corresponds to the Pleistocene to lower Pliocene. As at Site 465 , the sediments are represented by foraminifer-nannofossil and nannofossil-foraminifer oozes containing an admixture of siliceous organisms, mostly radiolarians (up to 5-10\%). The sediments are white, pale-gray, or greenish-gray. The varieties differing in color form mottles, lenses, and interbeds, their thickness being a few millimeters to some dozens of centimeters.

Grains of glauconite, irregular particles of acid and basic glass, and fragments of phosphates can be seen in thin sections under a microscope. The content of siliceous organisms (radiolarians, sponge spicules, silicoflagellates) is minimal at the base of the interval and increases appreciably upward.

The sediments always contain pyrite, forming segregations from a few micrometers to $0.2 \mathrm{~mm}$ in diameter. They are often associated with skeletons of various organims. Clay minerals ( $<0.001-\mathrm{mm}$ fraction) are represented by illite, kaolinite, chlorite, and montmorillonite. Thickness of deposits of the facies is $\mathbf{4 6}$ meters.
The deposits are separated from the underlying sediments by a considerable hiatus.

\section{CONCLUSIONS}

The distribution of facies at Leg 62 and other sites is summarized in Figure 4. These data give an idea of the change of sedimentation conditions within two large rises of the central and north-western parts of the Pacific Ocean during the middle Cretaceous to Pleistocene.

An important feature of sedimentation of these two regions is a distinct transgressive character; this is pronounced in a transition from shallower-water sediments (up to near-shore or subaerial) of the initial stages, to deep-water sediments of the final stages of this time.

In the southern part of Hess Rise (Sites 465, 466) during the late Albian to early Cenomanian there was a shallow-water basin with numerous islands. Rather peculiar carbonate oozes consisting of remains of planktonic (mainly coccoliths) and benthic shallow-water organisms (bivalves, gastropods, foraminifers) accumulated in it. These organisms were brought from shallowwater zones into deeper water by gravity currents. Bottom waters of such a sea appear to have been characterized by low oxygen contents, thus preventing complete destruction of organic matter (zoo- and phytoplankton, remains of terrestrial plants). The islands existing there were rises of the basaltic basement and were covered by vigorous vegetation. Besides plant remains, products of decomposition of igneous rocks were supplied from them: fragments of feldspars, magmatic rocks, clay material. Some of the islands appear to have been volcanoes that erupted ash into the sedimentation basin.

Owing to the considerable unevenness of the basement surface, the depth of the sea basin varied. Thus, in the late Albian, sedimentation conditions at Site 466 were deeper-water than at Site 465 . It might be that at the beginning of the Albian in the vicinity of this site there was an island, judging from weathered basalts produced under subaerial conditions.

Foraminifer-nannofossil chalks with black and brown cherts, strongly silicified and thinly laminated limestones (porcellanites) and layered claystones rich in organic matter and glass fragments correspond to the Albian to Cenomanian at Site 310 (Larson, Moberly, et al., 1975). This assemblage is similar to early Aptian carbonate sediments from Site 463, accumulated in a relatively deep-water zone (Timofeev and Rengarten, this volume).

Reconstruction of the environment of Albian-Cenomanian sedimentation in the northern part of Hess Rise (region of Site 464) is less reliable, mostly because of very poor core recovery from the lower part of the section. Accumulation of Albian-Cenomanian carbonate sediments containing a fauna of benthic deep-water foraminifers likely took place in a deep-water oceanic zone. The presence among them of relatively shallow- 

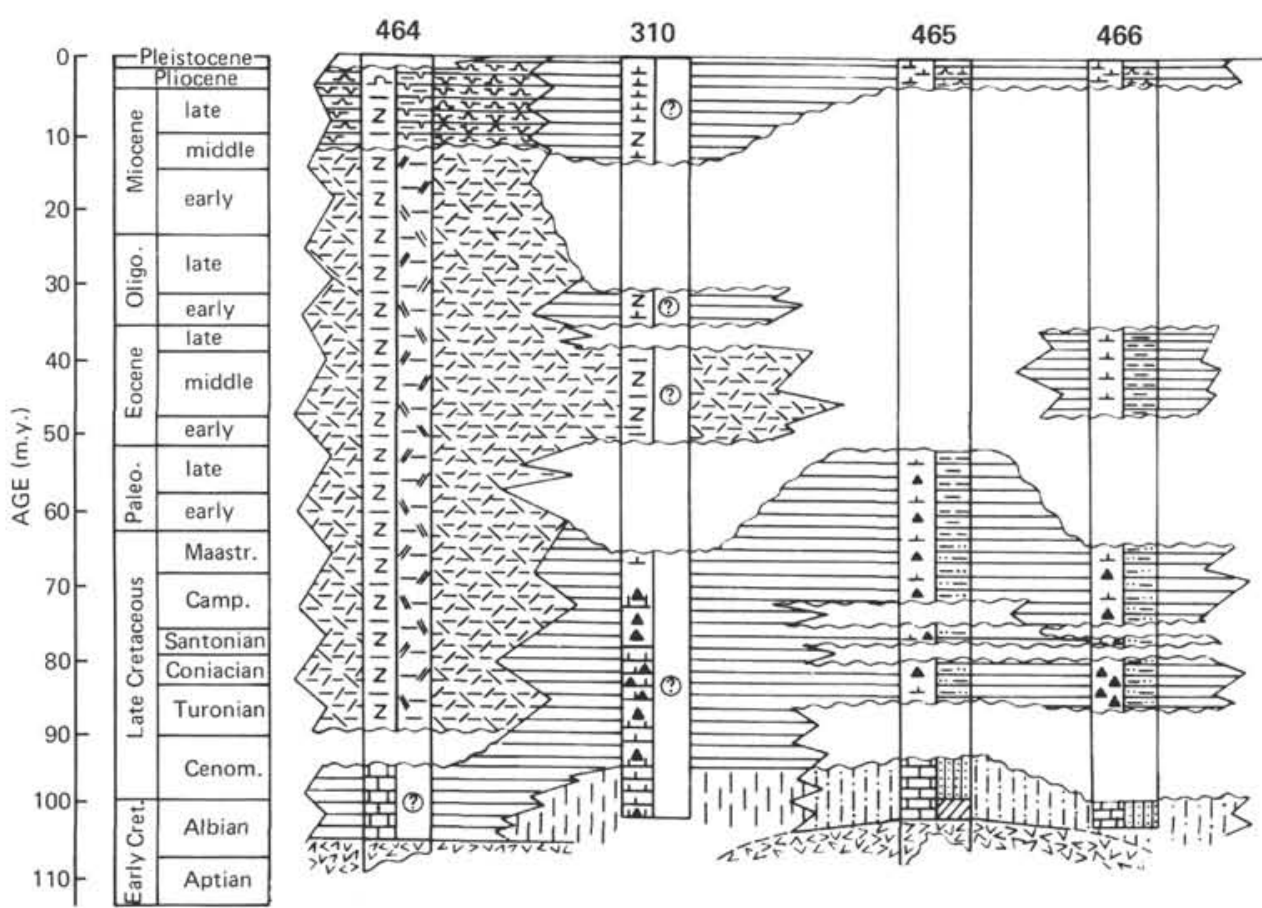

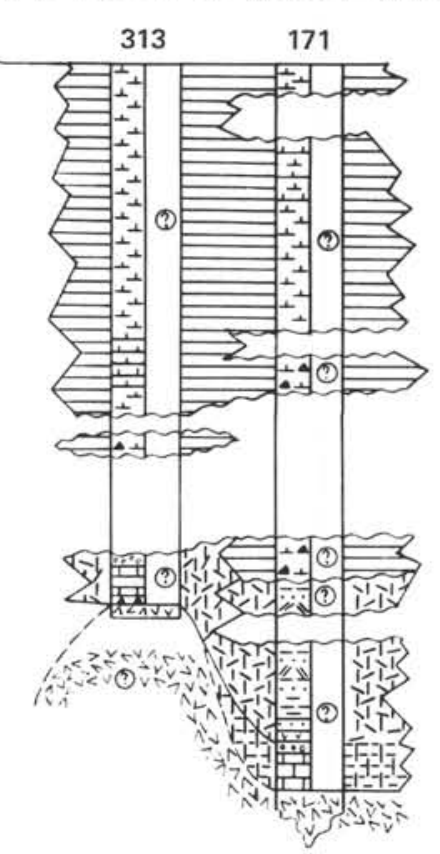

FACIES

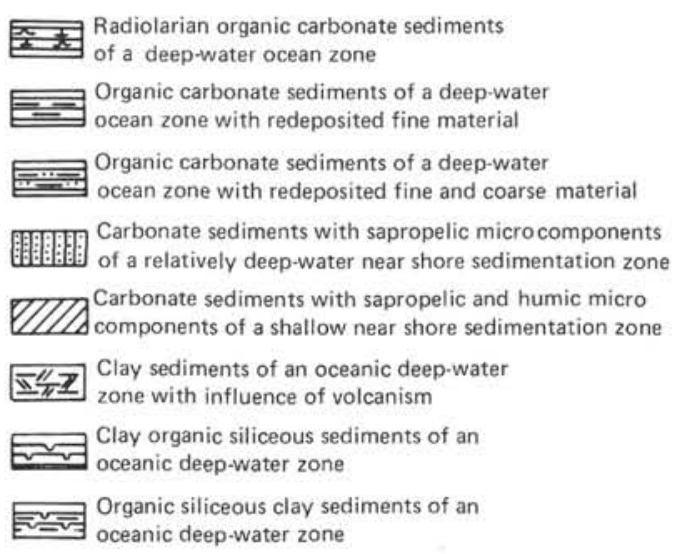

MACROFACIES

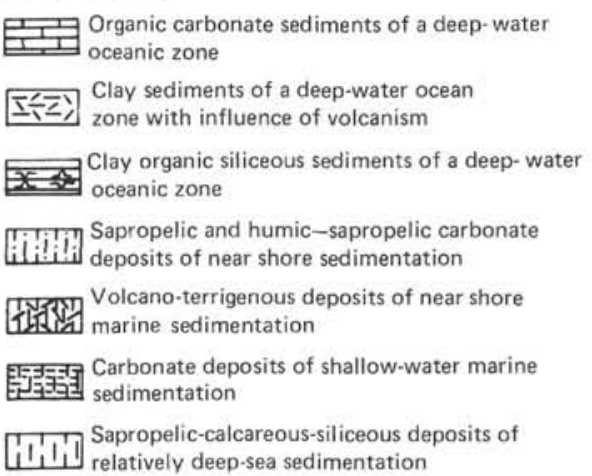

Organic carbonate sediments of a deep-water

적 Clay sediments of a deep-water ocean

Clay organic siliceous sediments of a deep-water

Ti:Ti Sapropelic and humic-sapropelic carbonate

Volcano-terrigenous deposits of near shore 选 marine sedimentation

琵望 sedimentation

i', i, relatively deep-sea sedimentation

Figure 4. Distribution of facies and macrofacies, Hess Rise and Mid-Pacific Mountains.

water inhabitants (foraminifers of neritic areas) is related to displacement of the material from the elevated parts of the bottom. The very presence of the carbonate organisms shows that the ocean depth at this site did not exceed the carbonate compensation depth.

Deep-water oceanic sedimentation developed in postCenomanian time of Hess Rise. In the northern part of the rise, brown and black clays rich in zeolites and reworked volcanic material-and, later, clay-radiolarian oozes-were deposited. The low carbonate content in these sediments (frequently it is absent) shows that the bottom surface was near or below the carbonate compensation depth.

In the southern and central parts of Hess Rise, deepwater foraminifer-nannofossil and nannofossil oozes accumulated in the region of Site 310 , while zeolite- bearing clays, brown and yellowish-brown, were deposited at Site 464. Accumulation of carbonate sediments on Hess Rise took place, as before, under conditions of strongly uneven underwater relief and the existence of shallow-water (along with deep-water) zones inhabited by benthic mollusks. Sediments of the shallowwater zone were brought into depressions of the underwater relief by gravity flows. Underwater rises were composed of igneous rocks. Some of them were volcanic structures; products of their decomposition (fragments of basalts or trachytes, plagioclases, basic volcanic glass, Fe-smectites) were displaced down the slope and deposited in deeper-water areas.

Redistribution of material was intensive through the Late Cretaceous and the first half of the Paleogene-the time of accumulation of the facies of organic carbonate 
sediments of a deep-water oceanic zone with redeposited fine and coarse material. These processes became much weaker during accumulation of the facies of organic carbonate sediments of a deep-water oceanic zone with redeposited fine material, and appear to have completely ceased in Pliocene to Quaternary time, during formation of the uppermost facies in the section. This peculiarity of sedimentation conditions was partly due to continuing increase of the oceanic depth and partly to the leveling of the underwater relief as a result of accumulation of a thick cover of sediments in lower areas and a thinner cover on higher ones.

In the northwest part of the Mid-Pacific Mountains (region of Site 171) at the end of the Albian and beginning of the Cenomanian, terrestrial conditions and formation of subaerial basalts are recorded. In the early Cenomanian, a sequence of carbonate oozes accumulated in shallow-water lagoons abounding in reef structures. At the end of the Cenomanian to the beginning of the Turonian, and up to the early Campanian, after manifestation of volcanic activity (a flow of subaerial or shallow-water basalts) volcano-terrigenous sediments alternating with carbonate oozes were deposited. Their lower part contains plant remains, sapropelic material, dinoflagellates, and shallow-water mollusks (Winterer, Ewing, et al., 1973). These appear to be a succession of shallow-water to deeper-water, near-shore sedimentation zone surrounding an island chain of volcanic origin. Conditions somewhat similar to those peculiar to the region of Sites 465 and 466 during Albian to Aptian time likely existed here.

In the region of Site 313 , the oldest of the penetrated Campanian to early Maastrichtian deposits are represented by alternating horizons of limestones and volcano-terrigenous rocks (breccias, sandstones, siltstones, clays) formed by gravity currents (Larson, Moberly, et al., 1975). Sediments of the lower horizons are enriched in benthic foraminifers, ostracodes, and plant spores. This apparently testifies to the proximity of land and their accumulation under near-shore conditions.

Beginning with the second half of the Campanian, or even the Maastrichtian, the conditions of deep-water oceanic sedimentation, which persist to the present day, appeared in this area of the Mid-Pacific Mountains. At that time, deep-water nannofossil and foraminifer-nannofossil oozes accumulated there.

Shallow-water marine (or even subaerial) conditions of the late Early to early Late Cretaceous in these areas of Hess Rise and the Mid-Pacific Mountains correspond to the conditions of much deeper-water oceanic sedimentation in a number of adjacent regions of the northwest and central parts of the Pacific Ocean. As mentioned above, the accumulation of deep-water nannofossil and foraminifer-nannofossil oozes took place in the vicinity of Site 464 , on the northern margin of Hess Rise. Brown, zeolite-bearing clays accumulated in the region of Sites 303, 304, and 307, west of Hess Rise, and in the region of Sites 164, and 166, southeast of the MidPacific Mountains; alternating brown, zeolite-bearing clays and foraminifer-nannofossil (likely deep-water) oozes formed in the region of Sites 169 and 170 .
Table 2 summarizes data on the character of sediments and recent depth of the ocean bottom at sites of the central and northwest parts of the Pacific Ocean. An important peculiarity is that large recent rises in this part of the Pacific, such as Hess Rise and the Mid-Pacific Mountains, were positive relief forms in the midCretaceous, although the conditions of sediment accumulation at that time were more shallow-water to subaerial. Thus, study of sedimentation conditions reveals an inheritance in development of this part of the Pacific Ocean throughout the Late Cretaceous and Cenozoic.

An important peculiarity of the sections penetrated by holes on the Hess Rise and the northeast part of the Mid-Pacific Mountains is the abundance of hiatuses (sometimes representing about $50 \%$ of the total encompassed geological time). Two kinds are distinguished: relatively short (from a few millions to 10 millions of years), and long, covering some dozens of millions of years. The former are represented by Late Cretaceous hiatuses at sites of the Hess Rise, and at Site 171, in the Mid-Pacific Mountains; such hiatuses are also recorded in Cenozoic deposits of both regions (at a single site, or less frequently at two adjacent sites). Long hiatuses are characteristic of the beginning and end of the Cenozoic and were recognized at most, but not all sites.

Analysis of the section given in Figure 4 shows that within Hess Rise the most numerous hiatuses, covering the longest time are peculiar to its southern part (Sites 465 and 466 ), this being a positive structure of the relief beginning from the middle of the Cretaceous. In the Mid-Pacific Mountains, the largest number of hiatuses is found at Site 171, on an elevation of the relief.

Pimm and Hayes (1972) emphasized that the upper boundary of a hiatus is most important for establishing its stratigraphic age, as it fixed the end of activity of the factors causing appearance of a hiatus. In some cases, the beginning of a hiatus at one site coincides with its completion at a neighboring one. Also noteworthy is the synchrony of completion of hiatuses at some sites, including those remote from one another. Thus, the end of the Cenomanian and the beginning of the Turonian represent the time of completion of the hiatus at Site 464; in the early Turonian, the hiatus at Sites 465 and 466 was completed. The end of the hiatus at Site 171 falls within the end of the Santonian, and that at Site 465 at the beginning of the Campanian. The hiatus at Site 310 was completed by the middle of the late Eocene. A more or less similar time of completion of the long early Cenozoic hiatus is fixed at most of these sites: at Site 310, the end of the Paleocene; at Sites 466 and 313, the beginning of the middle Eocene; at Site 171, the middle of the middle Eocene. According to Douglas et al. (1973), the Eocene hiatus is of regional importance; it was established at all sites of DSDP Leg 17. A rather broad interval of time is characteristic of the late Cenozoic hiatus: at Site 310, middle Miocene; at Sites 465 , 466, and 171, Pliocene. At Site 171, this hiatus is short.

Hiatuses in oceanic sediments have been described in many articles (Rona, 1973; Kennett et al., 1972; Le Claire, 1974; Pimm, 1974; Bezrukov, 1976; Krasheninnikov, 1977). They were caused by various factors: 
Table 2. Sediments and modern water depths of sites of the central and northwest parts of the Pacific Ocean.

\begin{tabular}{|c|c|c|c|c|c|c|c|c|c|c|c|c|}
\hline \multicolumn{7}{|c|}{ Abyssal Basins } & \multirow{2}{*}{\multicolumn{4}{|c|}{ Hess Rise }} & \multirow{2}{*}{\multicolumn{2}{|c|}{ Mid-Pacific Mountains }} \\
\hline \multicolumn{3}{|c|}{ Northwest Pacific } & $\begin{array}{l}\text { Northeast } \\
\text { Pacific }\end{array}$ & \multicolumn{3}{|c|}{ Central Pacific } & & & & & & \\
\hline Site & Site & Site & Site & Site & Site & Site & Site & Site & Site & Site & Site & Site \\
\hline 303 & 304 & 307 & 164 & 166 & 169 & 170 & 464 & 310 & 466 & 465 & 313 & 171 \\
\hline $5609 \mathrm{~m}$ & $5630 \mathrm{~m}$ & $5696 \mathrm{~m}$ & $5485 \mathrm{~m}$ & $4950 \mathrm{~m}$ & $5391 \mathrm{~m}$ & $5774 \mathrm{~m}$ & $4637 \mathrm{~m}$ & $3516 \mathrm{~m}$ & $2672 \mathrm{~m}$ & $2161 \mathrm{~m}$ & $3484 \mathrm{~m}$ & $2293 \mathrm{~m}$ \\
\hline \multicolumn{5}{|c|}{$\begin{array}{l}\text { Pelagic, brown, zeolite-bearing clays with } \\
\text { radiolarian remains }\end{array}$} & \multicolumn{2}{|c|}{$\begin{array}{l}\text { Alternation of } \\
\text { pelagic, brown, } \\
\text { zeolite-bearing } \\
\text { clays and deep- } \\
\text { water carbonate } \\
\text { oozes }\end{array}$} & $\begin{array}{l}\text { Deep- } \\
\text { water } \\
\text { carbon- } \\
\text { ate } \\
\text { oozes }\end{array}$ & $\begin{array}{l}\text { Carbonate } \\
\text { oozes of a } \\
\text { relatively } \\
\text { deep-water } \\
\text { sedimenta- } \\
\text { tion zone }\end{array}$ & \multicolumn{2}{|c|}{$\begin{array}{l}\text { Carbonate oozes of } \\
\text { a near-shore sedi- } \\
\text { mentation zone }\end{array}$} & $\begin{array}{l}\text { Deep-water } \\
\text { part of a } \\
\text { near-shore } \\
\text { sedimenta- } \\
\text { tion zone }\end{array}$ & $\begin{array}{l}\text { Shallow- } \\
\text { water } \\
\text { part of a } \\
\text { near-shore } \\
\text { sedimenta- } \\
\text { tion zone }\end{array}$ \\
\hline
\end{tabular}

absence of sedimentation, slumping of sediments downslope (including turbidity currents), dissolution of carbonate sediments, duration of underwater currents (the change of rate and direction of which is due to changes of climate), position of continents, rises or falls of world sea level. There are no reliable criteria for recognition of each of these factors.

Considering the wide distribution of redeposited material among the sediments (basalt fragments, older fauna within relatively young deposits, remains of shallow-water fauna enclosed in the undoubtedly deepwater sediments), we may assume that the many hiatuses are related to a considerable extent to redistribution of sedimentary material by gravity currents under conditions of uneven underwater relief. Some synchrony in appearance of hiatuses in various regions, including those remote from one another, was due to regional, not always strictly synchronous, factors-for instance, tectonic movements.

\section{REFERENCES}

Baturin, G. N., 1978. Phosphorites on the Sea Bottom: Moscow (Nauka).

Bezrukov, P. L., 1976. Hiatuses in deep-sea sedimentation and their geological significance. Paleontology. Marine Geology: Reports of Soviet Geologists to the International Geological Congress, XXV Session: Moscow (Nauka).

Bouma, A. H., 1962. Sedimentology of Some Flysch Deposits: Amsterdam (Elsevier).

Byers, C. W., 1977. Biofacies patterns in euxinic basins: a general model. Soc. Econ. Paleontol. Mineral. Sp. Pub., 25:5-17.

Douglas, R. G., Roth, P. H., and Moore, T. C., 1973. Biostratigraphic synthesis: hiatuses and unconformities. In Winterer, E. L., Ewing, J. I., et al., Init. Repts. DSDP, 17: Washington (U.S. Govt. Printing Office), 905-910.

Fischer, A. G., and Arthur, M. A., 1977. Secular variation in the pelagic realm. Soc. Econ. Paleontol. Mineral. Spec. Pub., 25: 19-50.
Kennett, J. P., Burns, R. E., Andrews, J. E., et al., 1972. AustralianAntarctic drift, paleocirculation changes and Oligocene deep-sea erosion. Nature, 239:51-55.

Krasheninnikov, V. A., 1977. Significance of oceanic deposits for building up of stratigraphic scale of Mesozoic and Cenozoic. (Indian Ocean). Questions of Micropaleontology (Vol. 19): Moscow (Nauka), 124-227.

Kuenen, $\mathrm{Ph}$. H., 1953. Significant features of graded bedding. Bull. Am. Assoc. Petrol. Geol., 37:1044-1066.

Larson, R. L., Moberly, R., et al., 1975. Init. Repts. DSDP, 32: Washington (U.S. Govt. Printing Office).

Le Claire, L., 1974. Late Cretaceous and Cenozoic pelagic depositspaleoenvironment and paleoceanography of the Central Western Indian Ocean. In Simpson, E. S. W., Schlich, R., et al., Init. Repts. DSDP, 25: Washington (U.S. Govt. Printing Office), 481-512.

Philippov, D. M., 1968. Circulation and Water Structure of the Black Sea: Moscow (Nauka).

Pimm, A. C., 1974. Sedimentology and history of the north-eastern Indian Ocean from Late Cretaceous to Recent. In von der Borch, C. C., Slater, J. G., et al., Init. Repts. DSDP, 22: Washington (U.S. Govt. Printing Office), 469-476.

Pimm, A. C., and Hayes, D. E., 1972. General synthesis. In Hayes, D. E., Pimm, A. C., et al., Init. Repts. DSDP, 14: Washington (U.S. Govt. Printing Office), 955-976.

Rona, P. A., 1973. World unconformities in marine sediments related to eustatic changes of sea level. Nature, 244:25-26.

Timofeev, P. P., 1968. Lithologo-facies and formational analysis of coal-bearing deposits. Reports of the International Geological Congress, XXIII Session, Czechoslovakia: Proceedings of Section 11, Origin of Coal Deposits: Prague (Academia).

, 1969. Geology and facies of the Jurassic coal-bearing formation in southern Siberia. Trudy GIN, Akad. Nauk SSSR, 197.

Timofeev, P. P., Rengarten, N. V., and Eremeev, V. V., 1979. Peculiarities of Meso-Cenozoic sedimentation in the Bay of Biscay and Rockall Plateau Regions, Leg 48. In Montadert, L., Roberts, D. G., et al., Init. Repts. DSDP, 48: Washington (U.S. Govt. Printing Office), 677-702.

Winterer, E. L., Ewing, J. I., et al., 1973. Init. Repts. DSDP, 17: Washington (U.S. Govt. Printing Office). 

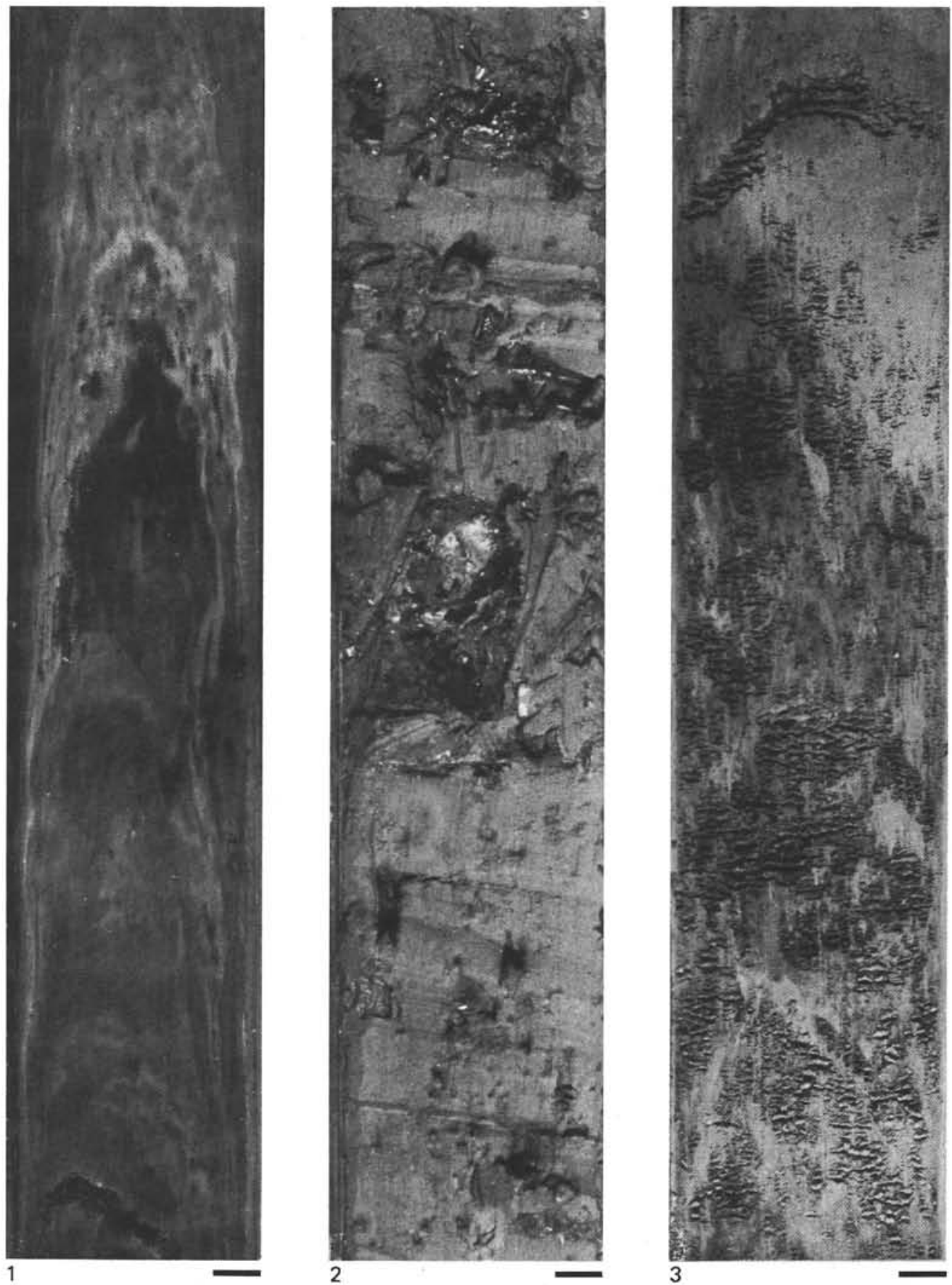

Plate 1. Sediments.

Figure 1. Clay, brown, dark-brown with mottles and streaks of yellow-brown and pale-yellow-brown color. Irregular horizontal lamination, intensively disturbed by drilling. The facies of clay sediments of a deep-water oceanic zone with influence of volcanism. 464-7-4, 10-45 cm. The scale bar in this and other photos is equal to $1 \mathrm{~cm}$.
Figure 2. Zeolite clay, dark-brown with cherty fragments (black), and zeolite concretions (white). Note that the sediment is highly disturbed and the apparent bedding is an artifact of cutting the core. Facies of clay sediments of a deep-water oceanic zone with influence of volcanism. 464-10-4, 30-60 cm.

Figure 3. Siliceous clay, yellow-brown in the upper part, and brown in the lower part; unevenly colored with mottles and streaks. Facies of organic siliceous clay sediments of a deep-water oceanic zone. $464-4-4,35-65 \mathrm{~cm}$. 


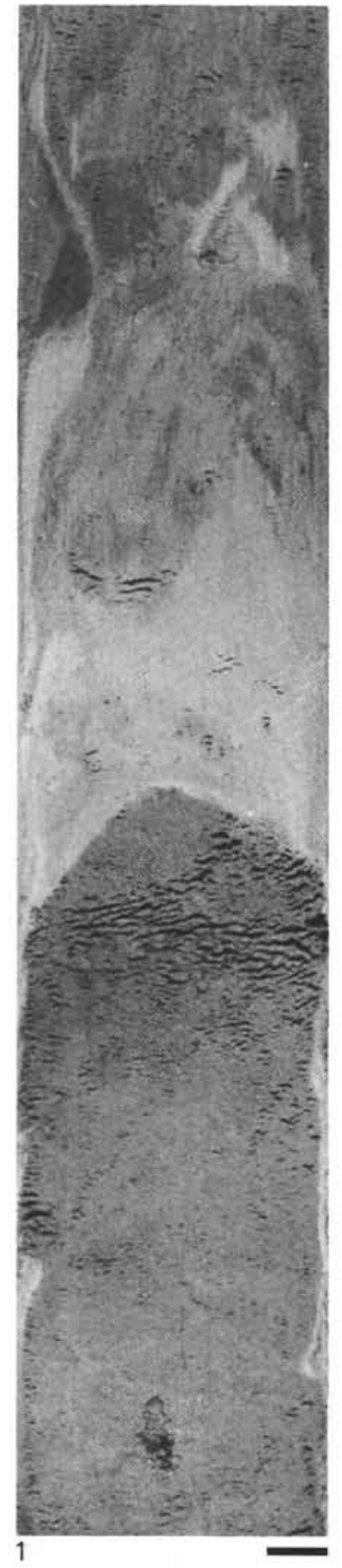

Plate 2. Sediments.

Figure 1. Clay diatom-radiolarian ooze, pale olive-gray or olive. Non-laminated, with mottles and streaks. In places irregular horizontal lamination disturbed by drilling. Visible distinct contact of multicolored varieties. Facies of clay organic-siliceous sediments of a deep-water oceanic zone. $464-2-5,65-100 \mathrm{~cm}$.

Figure 2. Diatom radiolarian ooze, sometimes radiolarian clay, pale olive-green or pale-gray. Homogeneous, nonlaminated. Visible

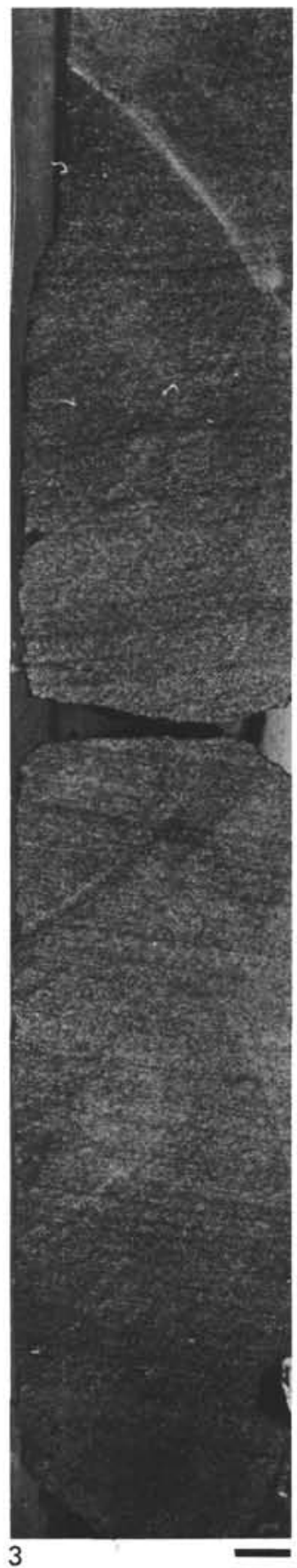

3

distinct contact of varieties differing in color. Facies of clay organic siliceous sediments of a deep-water oceanic zone. 464-2-4, $35-65 \mathrm{~cm}$.

Figure 3. Recrystallized foraminifer-nannofossil limestone, olive-gray or dark olive-green, with distinct horizontal lamination due to alternation of thin interbeds of different color and content of organic matter. Facies of carbonate sediments with autochthonous sapropelic microcomponents of a relatively deep-water near-shore sedimentation zone. $465 \mathrm{~A}-33-2,35-65 \mathrm{~cm}$. 


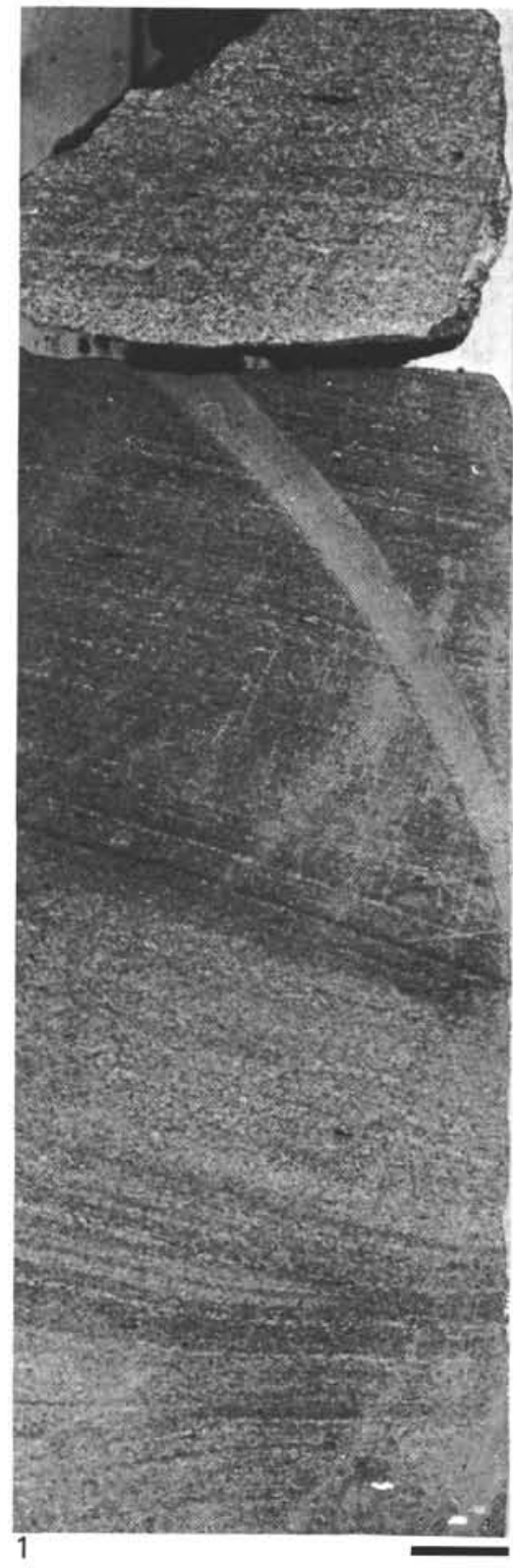

Plate 3. Sediments.

Figure 1. Recrystallized foraminifer-nannofossil limestone, olivegreen, now paler, now darker. Distinct small cross-lamination, flattening at the base, seen as a result of alternation of thin interbeds differing in color and content of sapropelic material and foraminifers. Facies of carbonate sediments with autochthonous sapropelic and allochthonous humic microcomponents of a shallow, near-shore sedimentation zone. $465-40-1,90-110 \mathrm{~cm}$.

Figure 2. Recrystallized foraminifer-nannofossil limestone, olivegray. Distinct small cross-bedding flattened laminatiaon. Facies of
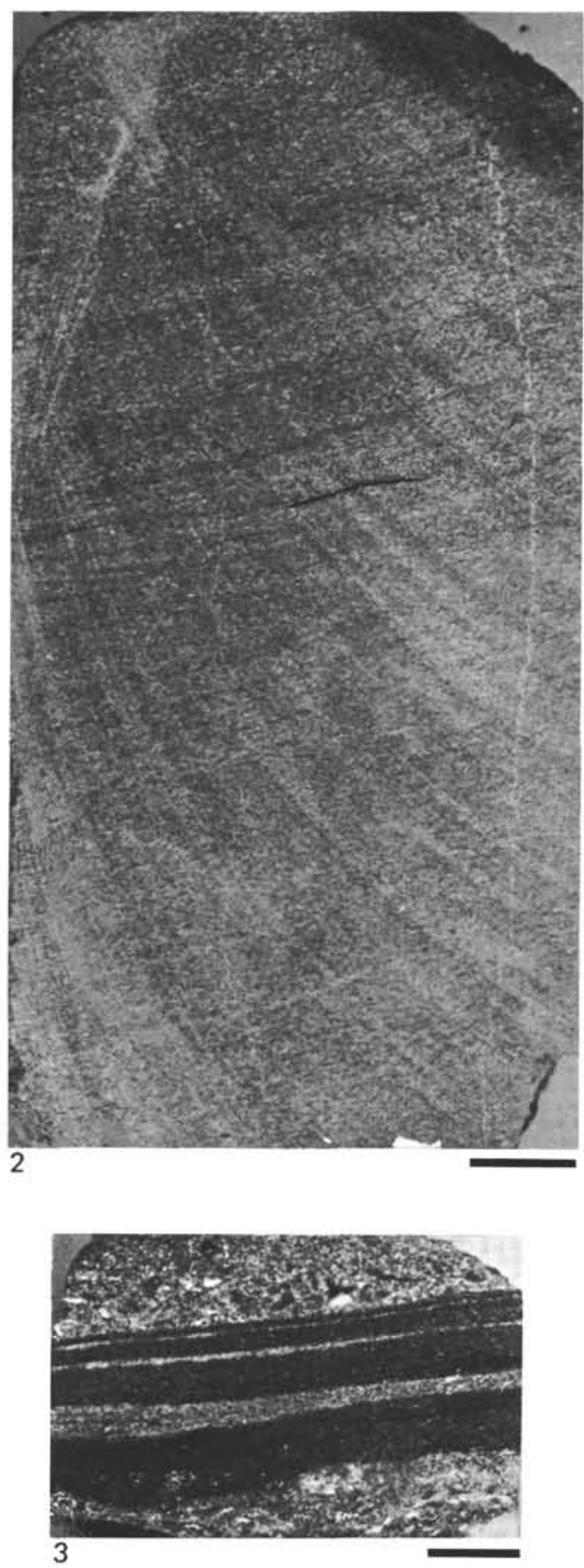

carbonate sediments with autochthonous sapropelic microcomponents of a relatively deep-water near-shore sedimentation zone. $465 \mathrm{~A}-30-1,60-70 \mathrm{~cm}$.

Figure 3. Recrystallized limestone with a high content of clastic material (mainly fragments of acid plagioclase); separate interbeds considerably enriched in organic matter, visible because of black color. Facies of carbonate sediments with autochthonous sapropelic and allochthonous humic microcomponents of a shallowwater, near-shore sedimentation zone. $465 \mathrm{~A}-40-1,120-123 \mathrm{~cm}$. 

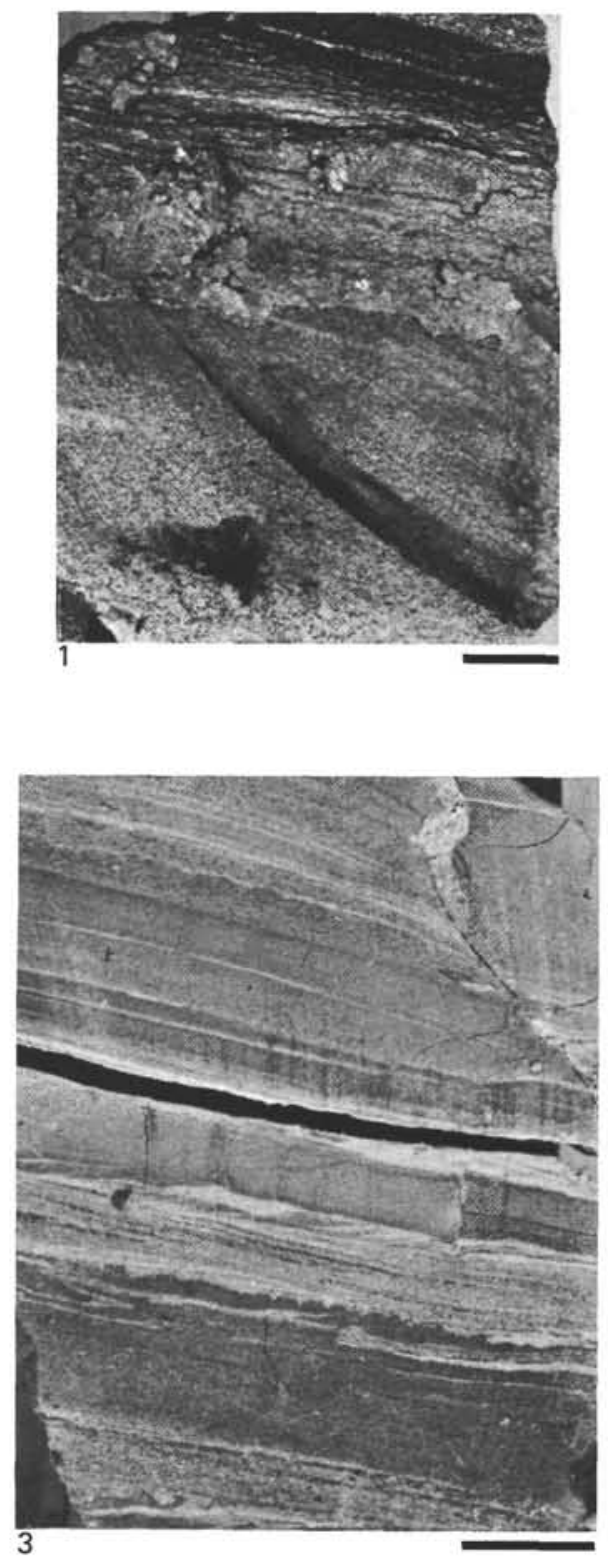

Plate 4. Sediments.

Figure 1. Recrystallized limestone with a high content of clastic components, distinct or indistinct horizontal and wavy lamination. In the upper part these are interbeds considerably enriched in organic material; below, pyrite segregations. Facies of carbonate sediments with autochthonous sapropelic and allochthonous humic microcomponents of a shallow-water, near-shore sedimentation zone. $465 \mathrm{~A}-40-1,125-140 \mathrm{~cm}$.

Figure 2. Volcanic ash with shards replaced by smectite. Distinct horizontal and small cross-lamination flattening to the base. Black interbeds are accumulations of organic matter. Facies of carbonate sediments with autochthonous sapropelic and allochthonous
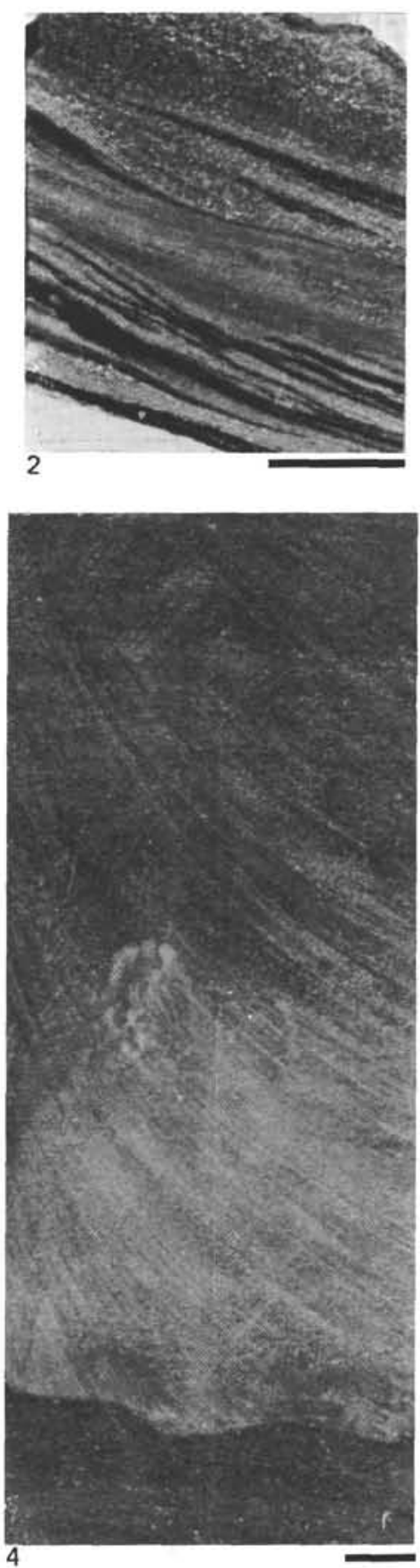

humic microcomponents of a shallow-water, near-shore sedimentation zone. $465 \mathrm{~A}-40-2,0-3 \mathrm{~cm}$.

Figure 3. Thin alternations of volcanic ash in which glass is replaced by clay material (dark-gray) and finely crystalline carbonate material (pale-gray). Horizontal and thin cross-lamination flattening to the base. The rock is broken by cleavage fractures. Facies of carbonate sediments with autochthonous sapropelic and allochthonous humic microcomponents of a shallow-water, near-shore sedimentation zone. $465 \mathrm{~A}-40-2,57-65 \mathrm{~cm}$.

Figure 4. Recrystallized limestone, olive-gray, partly non-laminated, partly with indistinct horizontal lamination. In the lower part is an uneven contact of darker and paler varieties. The color gradually grows darker upward. Facies of carbonate sediments with autochthonous sapropelic microcomponents of a relatively deep-water, near-shore sedimentation zone. $465 \mathrm{~A}-28-1,110-130 \mathrm{~cm}$. 


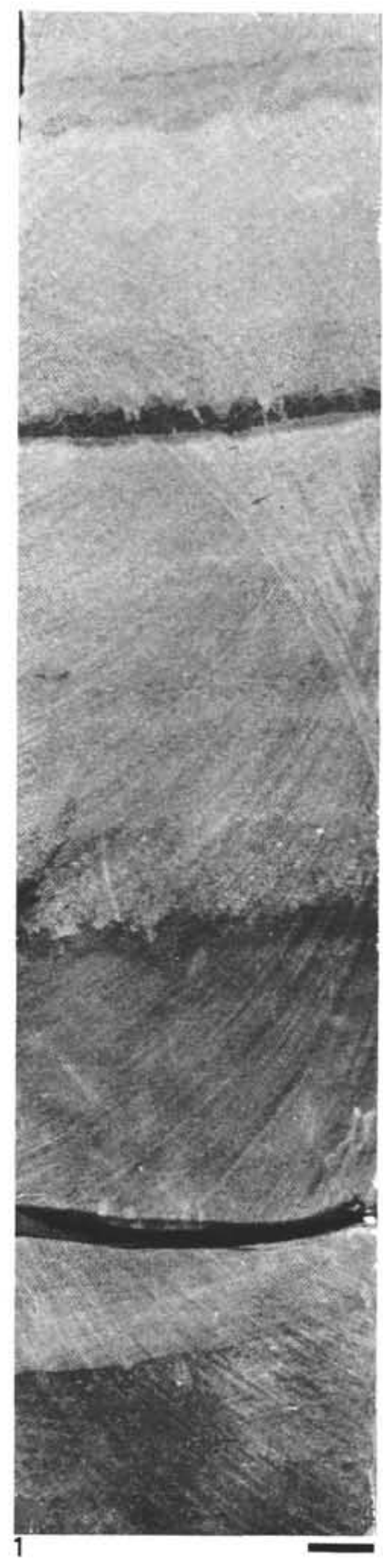

Plate 5. Sediments.

Figure 1. Recrystallized foraminifer-nannofossil limestone, olivegray, or gray, partly non-laminated, partly with indistinct horizontal lamination. Graded-bedding, indistinct lamination. The lower parts of two rhythms have very uneven, saw-shaped outlines. Facies of carbonate sediments with autochthonous sapropelic microcomponents of a relatively deep-water, near-shore sedimentation zone. $465 \mathrm{~A}-28-2,30-50 \mathrm{~cm}$.
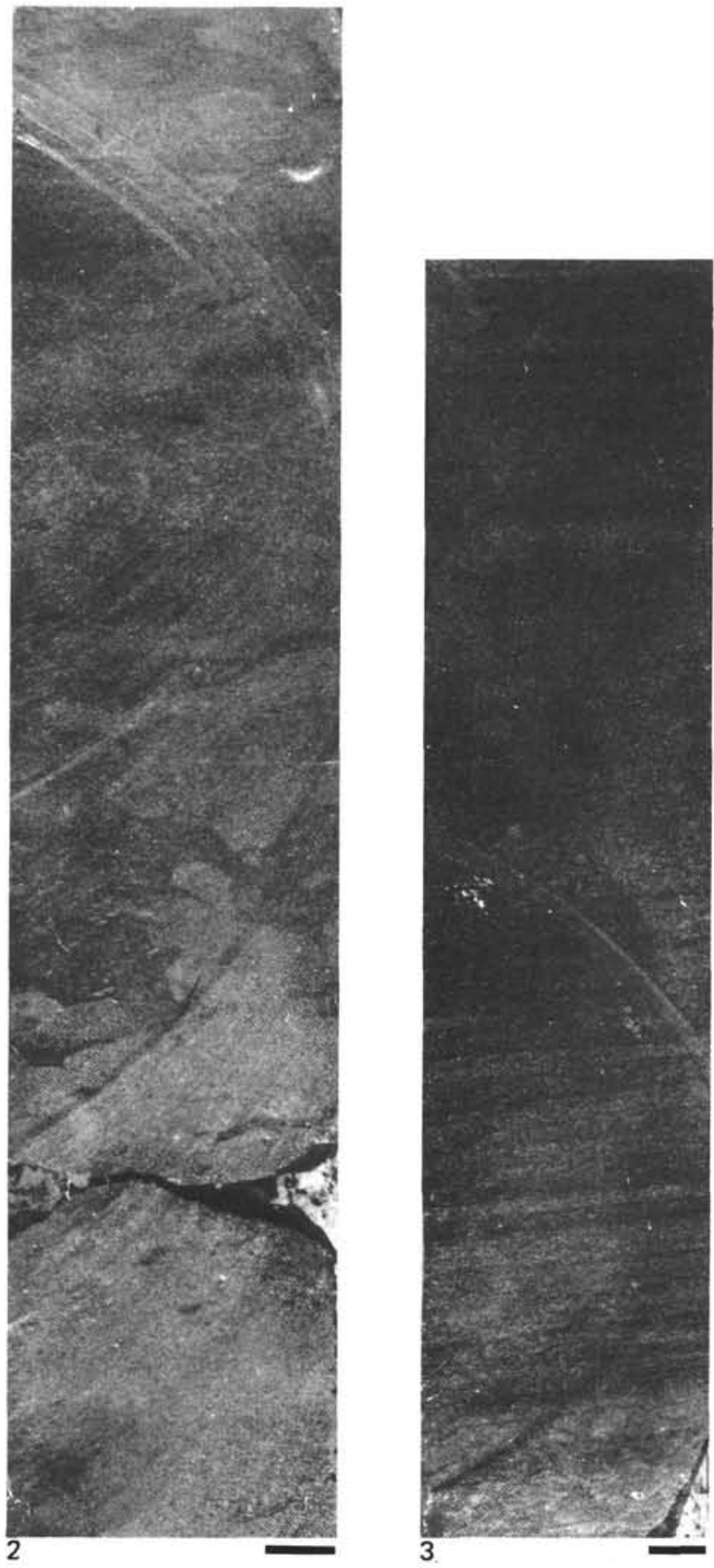

Figure 2. Nannofossil chalk. Olive-green or dark-gray, with irregular stirring structures. Facies of carbonate sediments with autochthonous sapropelic microcomponents of a relatively deep-water, near-shore sedimentation zone. $466-34-2,20-40 \mathrm{~cm}$.

Figure 3. Recrystallized foraminifer-nannofossil limestone, darkgray with an olive-green tint. Distinct horizontal lamination. Facies of carbonate sediments with autochthonous sapropelic microcomponents of a relatively deep-water, near-shore sedimentation zone. $465 \mathrm{~A}-27-2,80-110 \mathrm{~cm}$. 

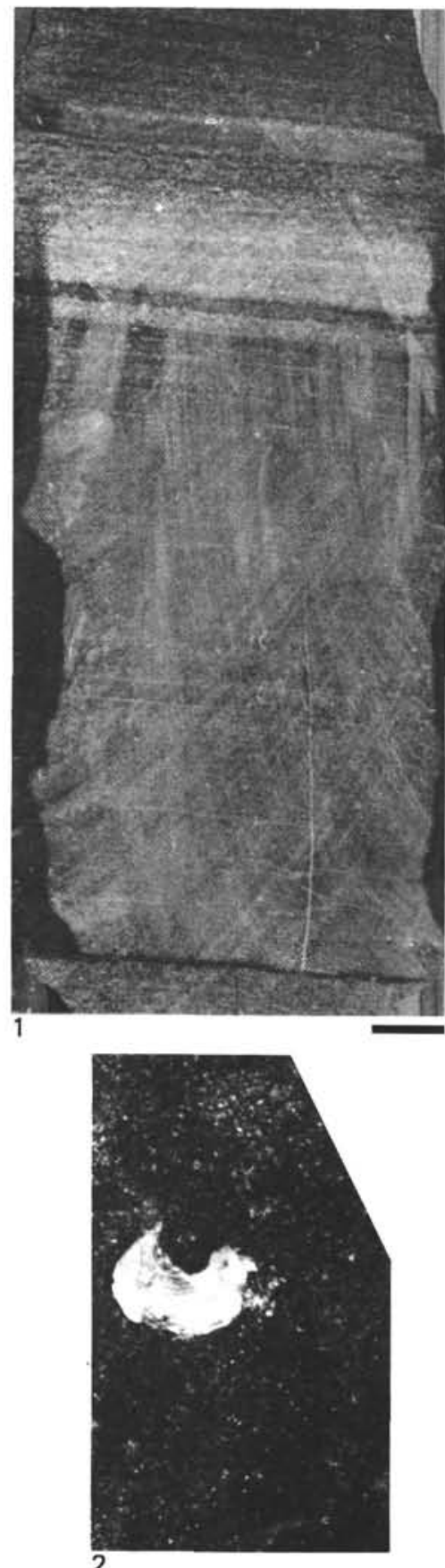

2

Plate 6. Sediments.

Figure 1. Recrystallized foraminifer-nannofossil limestone, gray, olive-gray to dark olive-gray. Distinct horizontal lamination due to alternation of differently colored layers, varying content of sapropelic matter and foraminifers. Facies of carbonate sediments with autochthonous sapropelic microcomponents of a relatively deepwater, near-shore sedimentation zone. $465 \mathrm{~A}-29,100-120 \mathrm{~cm}$.

Figure 2. General appearance of a mollusk fragment in a foraminifernannofossil limestone. Facies of carbonate sediments with autoch-
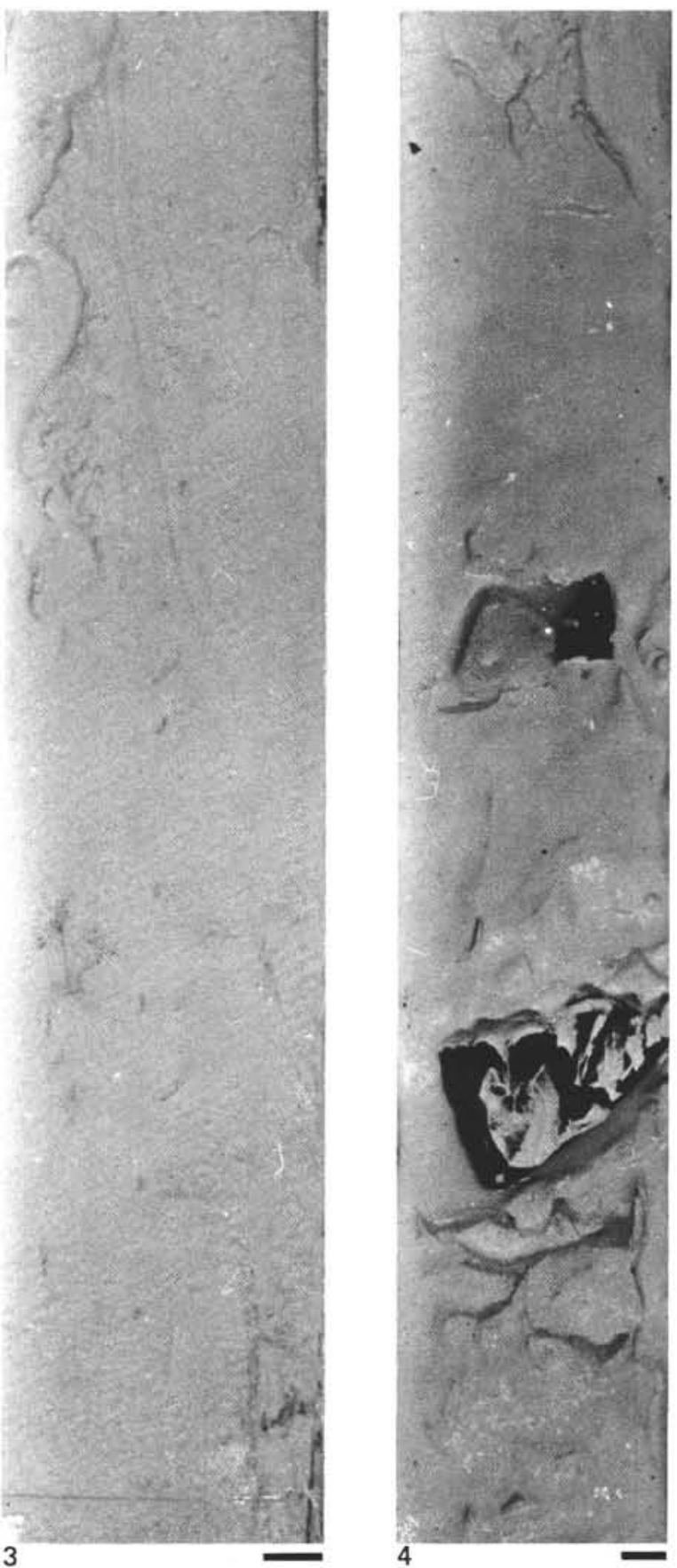

thonous sapropelic microcomponents of a relatively deep-water, near-shore sedimentation zone. $465 \mathrm{~A}-28-2,35 \mathrm{~cm}$.

Figure 3. Foraminifer-nannofossil ooze, white, soupy, intensely disturbed by drilling. Facies of organic carbonate sediments of a deep-water oceanic zone with redeposited fine and coarse material. $465-10-3,45-70 \mathrm{~cm}$.

Figure 4. Foraminifer-nannofossil ooze, white, soupy, intensely disturbed by drilling: contains angular fragments of black chert and slightly rouned Inoceramus fragments. Facies of organic carbonate sediments of a deep-water oceanic zone with redeposited fine and coarse material. $465 \mathrm{~A}-9-1,20-50 \mathrm{~cm}$. 